Historic, Archive Document

Do not assume content reflects current scientific knowledge, policies, or practices. 



\section{Business Terms and Information}

\section{Please read carefully before ordering}

About Orders. To avoid labor and delay, use the order sheet sent with this catalog.

Write, or print, your name and address very plainly exactly as it should appear on the label of your shipment.

Order as early as possible for later shipment to be sure of getting all the varieties wanted. Of the more popular varieties our stocks sometimes become broken before the close of the season.

Acknowledgment. You will receive from us a prompt acknowledgment of your order-a yellow sheet, showing all items exactly as we have them recorded for shipment, the total amount of the order and the amount of remittance received. If this is not correct in every detail, or if you wish any changes or addicions made, please nocify us at once. If for any reason we cannot fill any item on your order with good stock, you will be promptly notified; and that part of your money paid will be returned.

Terms. Remittances must accompany all orders. We do not make C. O. D. shipments of perishable Irises.

Transportation. We do not pay transportation charges. Orders will be shipped by express collect, unless transportation charges are added to the amount of your remittance. If small orders are wanted by parcel post, send $15 \mathrm{cts}$. for the first root and $5 \mathrm{cts}$. for each additional root orderedthus, 3 roots, 25 cts.; 7 roots, 45 cts.

How to Remit. Make remittances by Post Office Money Order, Bank Draft, or Personal Check payable to Indian Spring Farms, Inc., and not to individuals. Do not send silver or currency except by registered letter. U. S. Postage Stamps will be accepted in payments less than $\$ 1.00$.

Substitutions. No substitutions will be made unless your order so requests. With your permission, we are glad to send as a substitute a similar variety of equal or higher value, when possible, for any item we are unable to fill.

Claims. We guarantee the safe arrival of shipments to any point within the United States, but cannot be responsible for losses occurring during transportation on shipments to foreign countries. All claims must be made promptly on receipt of goods.

Shipments. We begin shipping Irises as early in the spring as the weather will permit, usually about March 15ch, and continue until groweh is too far advanced for safe handling. Late orders will be held until after July 15th. New and rare varieties not yet available in quantity cannot be supplied until after the flowering season.

Size of Roots. All roots shipped will be of standard size as recognized by the Growers' Association - selected single rhizomes of size and development obtainable at the time the order is filled. It should be remembered that different Iris varieties vary much in the size of their rhizomes. We always send good average roots of the varieties ordered.

Guarantee. All plants shipped are guaranteed to be true to name, vigorous and healthy. Should any error occur in labeling, or otherwise, and any bulbs shipped eventually prove untrue, we will replace them with true stock, and you may keep the plants first sent. 


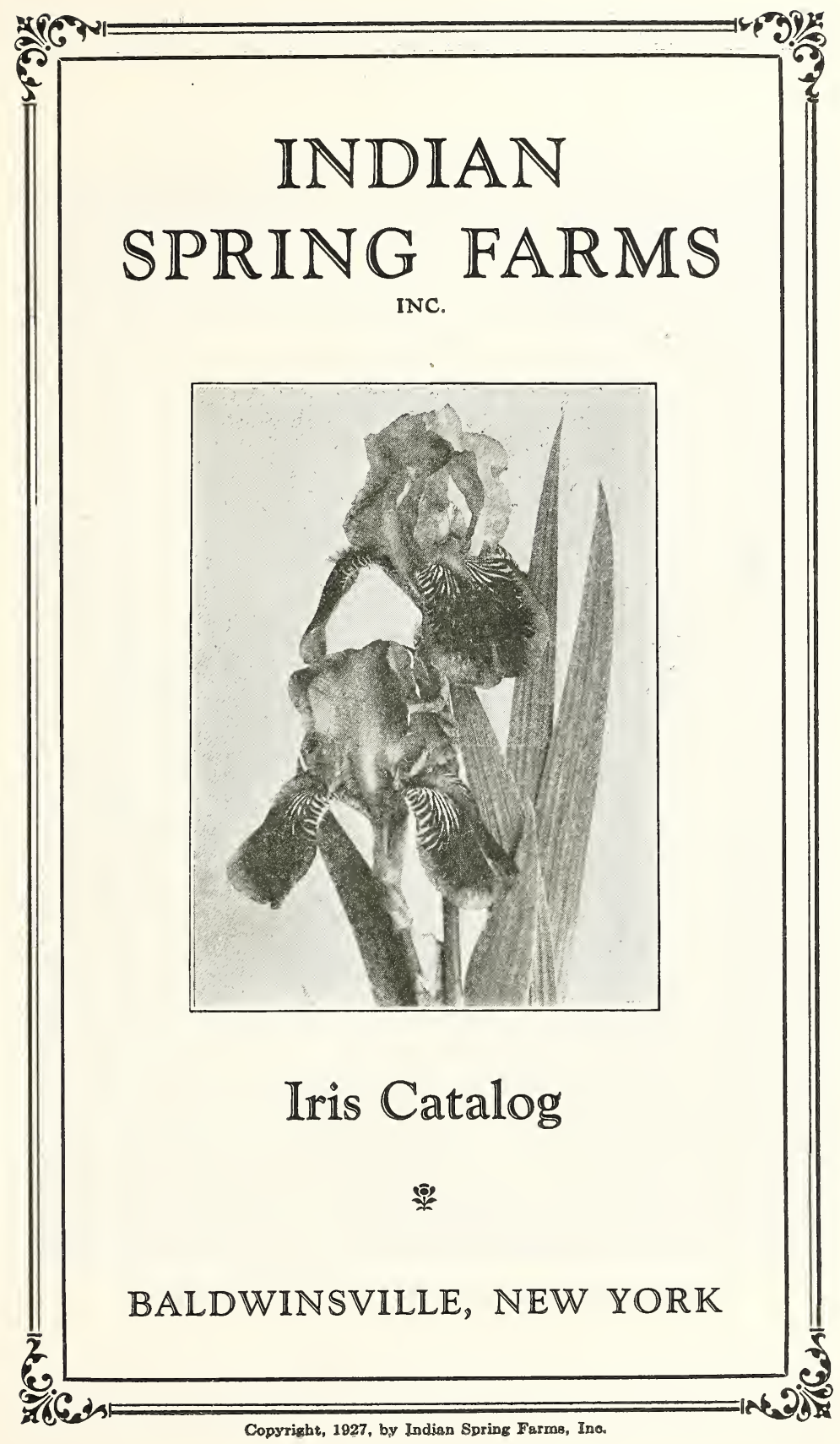


INDIAN SPRING FARMS, INC.

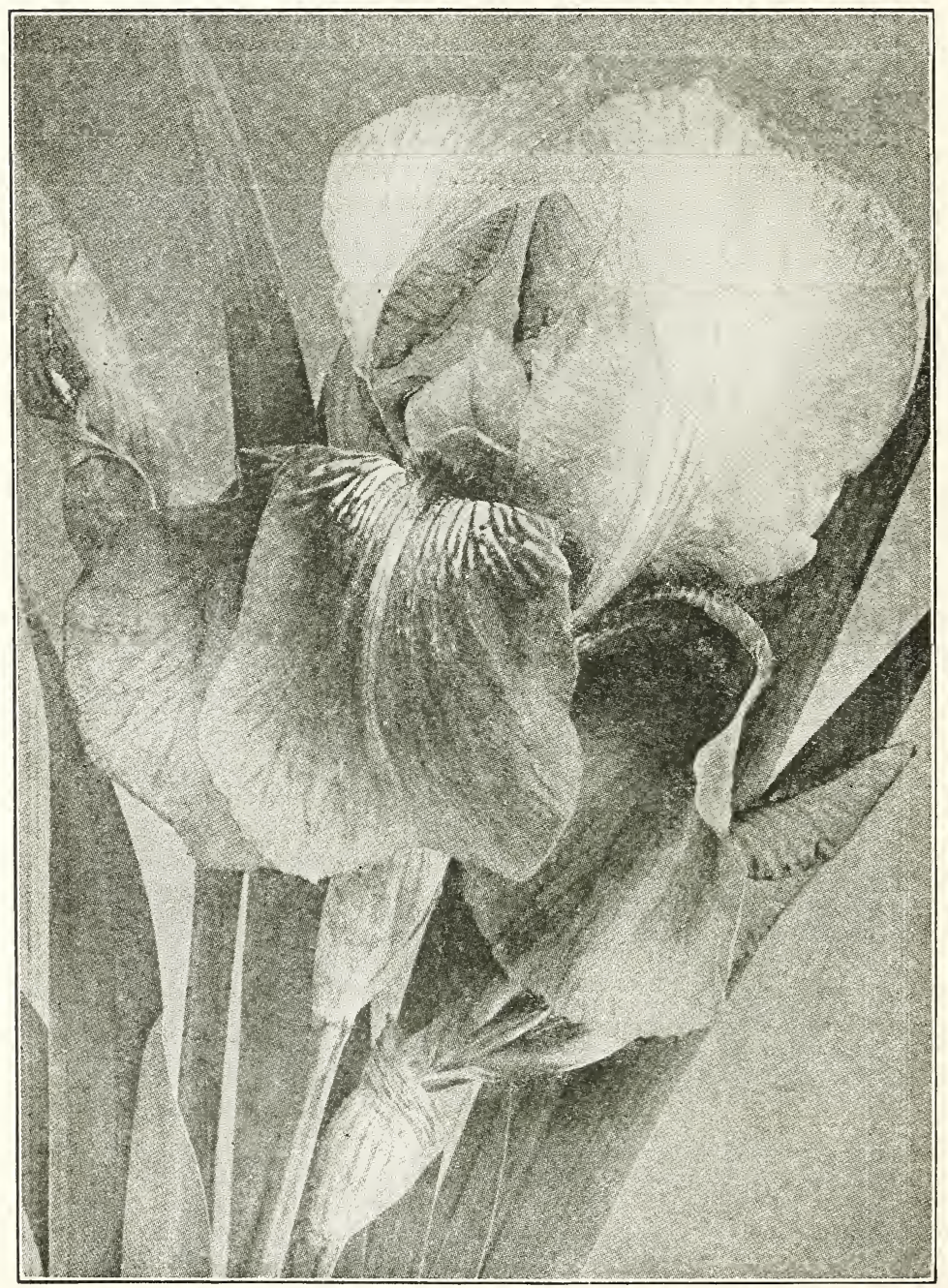

Lent A. Williamson, one of the finest American Irises 


\section{Introductory}

xมี่:

\section{About Irises in General}

D F ALL the garden flowers in general cultivation, the Iris today is undoubtedly the most popular. In its various forms and species, it is found growing wild and under cultivation in all climates and in all parts of the world. In the United States, it has been voted to be the most popular of all the perennials.

This popularity of the Irises is due both to the wonderful beauty of the flowers and to the comparative ease with which they can be grown in almost all gardens, now that their culture is better understood. As individual plants the Irises are attractive. The vigorous growth of the wide, sword-like foliage of the bearded varieties, produced in broad, spreading, fan-like sheaves, and the long, drooping, grassy leaves of the beardless species-both produced in rich and varied shades of green-are artistic and beautiful. They lend themselves admirably to well-planned garden plantings, and are of value to the landscape architects in producing desired border effects. The flowers themselves, produced on stems of varying heights, are the most wonderful color creations imaginable. From rich, dark hues of purples and blues, they range through smoky, cloud-like shades of buffs and grays, to delicate orchid tints and rainbow effects that are almost etherial. In the words of a little child, they are most aptly described as "most every kind of fairy colors." In mass plantings their garden effect is beyond description in words.

Those who began growing Irises twenty or thirty years ago can best appreciate the increase in popularity of the flower, and the wonderful development that has been made by hybridizers in producing the flowers of im: mense size and rich coloring, such as we have today, borne on plants of improved growth, with stems of tall and branching habits. It is in the class of Bearded Irises that the improvement is most marked. A planting with such old standard varieties as Hebe, Flavescens, Mme. Chereau, Maori King, Darius and Amas as its features, would not rate very high in comparison with a collection of the newer Irises such as Ambassadeur, Ballerine; Asia, Aphrodice and the Dominion Seedlings.

Most Irises are easy to grow, and, they will do well for even the most inexperienced gardener, if these simple facts are kept in mind. In general, they are sun-loving plants and thrive best in the driest of soils where drainage is perfect and where the rhizomes can "bake" in sunshine after the flowering season. They will not do well if planted in the shade, or in damp places where water stands during any part of the year. The few exceptions to this general rule will be noted under the descriptions of varieties, and in our cultural directions for Beardless varieties.

airis.

\section{Plan an Iris Garden}

While Irises are adaptable to almost any planting and do well either in a general garden arrangement or in a mixed border among other perennials. 
they are at their best when planted alone in beds or in a separate Iris garden. Such a garden, worked out along natural lines rather than in formal arrangement, with irregular massed plantings and grassy pathways of varying contour, becomes a spot of endless pleasure to its owner; and it affords unlimited possibilities for an expression of one's creative ability in the use of the different Iris species in their various forms, habits of growth and colorings. As Irises may be successfully moved most any time of the year, even when in full bloom, if given water until they become reestablished, and as they readily adapt themselves to new locations and give quicker blooming results after moving than most perennials, they are ideal for the working out of such a garden.

Beginning its season with the early-flowering Dwarf Bearded Irises, the Pumilas, that come into flower early in April, followed in turn by the May flowering Intermediates, the Iris garden leads up to its climax in early June when the "German," or late-flowering Bearded Irises, come into bloom. These carry on in their wide range of color until near July when the Sibiricas and the other species of the Beardless class afford a show of beauty in a different form than any Irises that have gone before. Last of all, the Kaempferi, or Japanese Irises, hold attention in a display of true Oriental splendor that is wonderful to behold. So the Iris garden is an ever-changing spot of interest and beauty throughout the spring; and Iris Time laps well over into Peony Time, affording a fitting prelude to the gorgeous splendor of that wonderful flower.

xir.

\section{How to Grow Irises}

Most Irises are easy to grow and will thrive in almost any kind of soil and in a position where other things will not do well, provided it is well drained. Contrary to the somewhat prevalent idea that Irises are, by nature, water-loving plants, most of them cannot be grown successfully in poorly drained soil or where water stands about their roots any part of the year. Because they are so adaptable, they are often looked upon as something to fill a difficult spot in the garden and consequently do not receive the cultivation they deserve. No plant more adequately repays for good and proper cultivation.

The Beardless Irises prefer somewhat different soil conditions from the Bearded classes, so we consider them separately in these cultural recommendations.

\section{Bearded Irises. Pages 6 to 38}

Plant Bearded Irises in the sunniest and best drained places in the garden. They require the moisture supplied by the seasonable rains during the growing season, but resent wet feet and will not do well in naturally damp soil, or where water stands about the roots during any portion of the year. They enjoy the sunshine, and the more their rhizomes "bake" in the hot sun during the rest period after flowering, the stronger and healthier their fall growth will be.

Prepare the ground for planting by spading deep. Soil of ordinary garden quality does not require special fertilization. The Bearded Irises are limeloving plants, and soils not naturally alkaline are improved by the addition of a liberal application of air-slacked lime well forked in. Crushed limestone rock or pulverized old mortar rubble is very beneficial when mixed in quantity 
with heavy soils. With sand or very poor soils, peat or humus in some form may be added, and commercial fertilizer or bone meal forked in in limited quantity. Do not use stable manure in soil intended for Bearded Iris. If plantings are to be made in special beds or in a separate Iris garden, elevate the surface of the beds several inches above the level of the surrounding ground by spading deep and bringing in additional dirt.

Bearded Irises may be planted successfully at any time when the ground is tillable, even when in full bloom, if moisture is supplied until the root-growth becomes established. The rest period just after the flowering season-during July and August in this climate-is the ideal time for transplanting. That is when we make our own plantings and when we prefer to ship Irises to our customers.

Irises are shipped dry and should be planted as soon as received. Our plants will come with the tops properly trimmed and the roots pruned back ready for planting. Should they be received with the tops dried out and the roots more or less shriveled, so much the better because that indicates that the rhizomes are in their dormant state.

Plant shallow so the rhizome, or fleshy part of the root, lays in horizontal position and is barely covered. Press the soil firmly about the roots so that the rhizome is anchored securely in the earth and not rocked by the wind. Do not water unless the soil is very dry, and then only to settle the soil about the roots. Keep the plantings free from weeds by frequent but shallow cultivation, and do not allow them to become overgrown by other plants in a way to shade the rhizomes and cut off the air. Let the sun bake the rhizomes! Set the roots about a foot apart in rows or in clumps, and transplant when they become crowded, about every third year.

Special consideration must be given to the Bearded Irises of Ricardi parentage mentioned in this list. These are mostly introductions from Denis and Millet, and include some of the most beautiful Bearded varieties, well worth the special attention necessary for their successful growth. Like the parent species, they are all strong, robust growers under favorable conditions, and produce flowers of magnificent coloring on tall, rigid stems. They are, however, somewhat difficult to handle in the colder climates unless their requirements are well understood. They withstand the cold of winter quite well, but they are highly susceptible to the dampness of early spring. They should be planted in a dry and warm location where the under drainage is perfect, and given slight protection in the late winter by covering with a frame that will protect them from the wet and yet admit free circulation of air. Our descriptive texts indicate the varieties that need such special care.

\section{Beardless Irises: Pages 38 and 39}

Most Beardless Irises differ from the Bearded classes in that they object to lime and prefer a more acid soil condition made rich with manure. They also thrive in damp locations, provided the rhizomes are above the level of standing water. The Sibiricas and the Species with grassy foliage should never be planted in limed soil, but are perfectly at home in the damper locations or near the water's edge. The Spuria group, including Ochroleuca, Monspur and Shelford Giant, are more tolerant of lime, and do well in the cultivated rich border and respond to heavy fertilization. Tectorum, or the Roof Iris, demands a dry location in the full sun. Pseudacorus likes water, and will do 
well in the wettest places, yet it can also be grown to good advantage in the borders.

The Beardless varieties are best planted in the early spring before growth starts, or in the fall. They are packed damp for shipment and should not be allowed to dry out before planting.

iîn.

\section{General List of Bearded Irises}

In this list of Bearded Irises, we believe we are offering one of the most comprehensive collections cataloged by any grower. It includes the best of the older and better known Irises that are now obtainable at reasonable prices, as well as most of the new and rare introductions from originators in the United States, England, Germany and France.

As a guide to those who are not familiar with Iris varieties, we have designated the ratings of the different varieties as determined by the symposium of the American Iris Society, thus-Asia 92. Where no rating is given, the variety has not yet been rated by the society. While these ratings are not infallible, they very accurately depict the comparative merits of the different Irises.

Among the newer introductions are many wonderful Irises that far surpass most of the older varieties in the size of their flowers, their tall and branching stems and their unusual color blendings. While it will take the test of time to determine the reliability and the ultimate standing of many of these new things, they well portray the results of scientific hybridization and establish a new basis of quality in Irises.

Most remarkable of all are the Dominion Seedlings, introduced by Bliss. In these new Irises we have size of bloom, perfection of form, substance of petalage and a richness of coloring that marks a distinct advance. Their habits of growth leave chance for further improvement in height and branching, but any garden that boasts of the best should contain some of these fine new things. Bruno, Moa, Cardinal, Swazi, Duke of Bedford, Tenebrae and Glamour all have proved themselves in American gardens and Romola, Majestic and the still newer Zulu and Mrs. Valerie West are reputed to be even finer than the first. Many of the newer varieties from Perry, Millet and Cayeux and Leclerc are equally fine in their respective types, and bear wonderful large flowers on fine stems of almost perfect growth.

From American growers we also have a fine lot of new and better Irises that rival the foreign introductions for first attention. In the introductions of Mr. Williamson of the Longfield Gardens, we have vigorous and freeflowering varieties, that surpass the Goos and Koenemann introductions in distinctiveness, reliability and garden qualities. - Argynnis, George J. Tribolet and their 1927 introductions, Dolly Madison and Vesper Gold, are all Super-Irises of the highest class. Among the Mohr seedlings; introduced from California, we also find some distinct and deserving varieties. Valencia is unusual in its coloring and very beautiful. Frieda Mohr is a beauty, and William Mohr is about the most interesting new variety ever introduced. The fine things from the Sturtevant Gardens, need no comment from us; the Sass Plicatas form a class by themselves; and Mr. Shull's Morning Splendor, with its honors won, speaks for the quality of the things from his garden. 
A. E. KUNDERD (Fryer 1927) 6.3. S. yellow-bronze, tinged with magenta; F. magenta-red, tinged with bronze, reticulated yellow from center to base; conspicuous orange beard; fragrant.

35 cts. each; 85 cts. for $3 ; \$ 3.00$ per doz.

AFTERGLOW (Sturtevant 1917) 8.3. Soft, misty lavender, shading to buff and lighted with rich yellow at the haft. A finely formed flower with a most pleasing harmony of color. 36 inches.

50 cts. each; $\$ 1.25$ for 3 .

AIXO (Lemon). A pleasing little Plicata of rose-white, penciled and margined with lilac. $\quad 25$ cts. each; 60 cts. for $3 ; \$ 2.00$ per doz.

ALBERT VICTOR (Barr 1885) 7.9. A medium large, self-colored flower of light hyssop-violet, veined brownish-purple at the haft; beard bluishwhite with yellow tips. Typical Pallida stalks; growth vigorous. 40 inches.

35 cts. each; 85 cts. for $3 ; \$ 3.00$ per doz.

ALCAZAR (Vilmorin 1910) 8.9. A very large, vigorous bicolor. S. slaty bluish-violet, overlaid bronze; F. deep reddish-purple, with a bronzeveined throat. 42 inches. Very similar to Lent A. Williamson, and one of the finest of the older Irises.

35 cts. each; 85 cts. for $3 ; \$ 3.00$ per doz.

ALVARADO (Mohr 1926). Very tall, with blooms of deep, rich purple. A fine Seedling of Conquistador and Lent A. Williamson. $\$ 2.50$ each.

AMAS (Species) 7.8. A large, early-flowering species from Asia Minor, collected by Foster in 1885. Broad but somewhat floppy standards of light hyssop-violet, finely veined at the base; falls smooth petunia-violet, broad and well expanded; long, bright yellow beard. Growth vigorous, with stems low and well branched. 30 inches.

35 cts. each; 85 cts. for $3 ; \$ 2.00$ per doz.

AMBASSADEUR (Vilmorin 1920) 9.4. Very large flower, with smoky, reddish-violet standards and dark velvety purple-maroon falls, of good texture, that keep an almost horizontal position; beard and styles yellow. Magnificent, rich flower growing on a strong stem. 48 inches.

90 cts. each; $\$ 2.50$ for 3 .

AMBIGU (Vilmorin 1916) 8.3. S. beautiful smoky red; F. velvety reddish-brown. A good, strong-growing and free-flowering variety. 30 inches.

50 cts. each; $\$ 1.25$ for 3.

ANNA FARR (Farr 1913) 8.4. S. white, lightly bordered pale blue; F. pure white, with pale blue markings at the base. A large flower with broad petals of good substance. The horizontal falls produce an orchidlike effect. : 35 inches. This variety has become badly mixed in commerce. The true variety is very beautiful, but must be grown in welldrained soil.

$\$ 1.00$ each; $\$ 2.50$ for 3 .

ANNE LESLIE (Sturtevant 1917) 7.7. S. white, faintly flushed rose; F. dahlia-carmine: A very clean and attractive variety, especially pleasing in mass planting. 30 inches. $50 \mathrm{cts}$. each; $\$ 1.25$ for $3 ; \$ 4.00$ per doz.

ANN PAGE (Hort 1919) 8.6. A lovely pale blue with large flowers of splendid shape. S. and F. pale lavender-blue; F. heavily penciled brown at the haft. Stems stout and erect. 36 inches. Similar in color to Crusader. The finest Iris of its color class, and is always included in a list of the best varieties.

$\$ 3.00$ each.

ANOSIA (Williamson 1925). S. of the rich, brown tone found in some of the Breeder tulips; F. golden red. Flowers freely produced on 30 -inch stems. Rich, distinct and good. $\$ 1.00$ each. 
ANTONIO (Hort 1921). A large-flowered bicolor. S. light lavenderviolet, erect; F. anthracene-violet with redder lights; haft amber at the edges; beard conspicuous, orange tipped. Early. 36 inches. $\$ 2.50$ each.

APACHE (Farr 1926). S. coppery vinous purple, shading lighter at the base, with dark brown reticulations; F. a dark crimson-brown, with heavy light-colored reticulations; beard yellow; stigma buff, shaded violet. A large flower with dome-shaped standards and wide-spreading falls. Strong, vigorous grower. 20 inches.

$\$ 10.00$ each.

APHRODITE (Dykes 1922). A clear, bright violet-pink self, with no veinings to detract from its loveliness; haft white, with a lemon beard. Blooms are of fine substance with smooth, glossy texture, and do not bleach; sweetly scented. Flowers freely. A truly "finished" Iris, and the best of the so-called pinks.

$\$ 10.00$ each.

ARCHEVEQUE (Vilmorin 1911) 8.3. S. deep purple-violet; F. rich, deep, velvety violet. An exceedingly fine flower of rich coloring. 24 inches.

$35 \mathrm{cts}$. each; $85 \mathrm{cts}$. for $3 ; \$ 3.00$ per doz.

ARGENTINA (Mohr 1924). A large-flowered, tall-growing variety, pure white with old gold haft, heavily veined with olive; conspicuous orange beard. 36 inches. A Caterina Seedling that has proved perfectly hardy in the North and East.

$\$ 5.00$ each.

ARGYNNIS (Williamson 1925). A tall and distinct Iris of Variegata coloring. S. strontian-yellow, narrowly margined and delicately shaded aniline-yellow; F. a solid, dark violet-carmine without reticulation, paling slightly at the border; haft yellow, veined maroon; beard yellow. Tall, slender stalk, carrying ten to twelve flowers. Late midseason. 40 inches.

$\$ 1.00$ each.

ARLEQUIN (Denis). A curious and interesting Variegata. S. oriental ochre, with purplish-black; F. dark purplish-black, veined white on a yellow ground. 28 inches.

$\$ 1.00$ each; $\$ 2.50$ for 3 .

ARNOLS (Barr) 7.8. S. slate-purple, flushed with Saccardo's umber; F. seraight-hanging, dusky auricula-purple, veined burnt umber; haft flus!ed lemon-yellow; beard orange. 36 inches.

35 cts. each; 85 cts. for $3 ; \$ 3.00$ per doz.

ARSACE (Millet 1919) 8.4. Large flowers of most pleasing shade. S. a soft shade of mauve, lightly waved; F. mauve, clouded soft rose. A tall, vigorous variety with thin stems. 36 inches.

50 cts. each; $\$ 1.25$ for $3 ; \$ 4.00$ per doz.

ASIA (Yeld 1920) 9.2. S. pale lavender, suffused and reticulated yellow at the base; F. light violet-purple, paler at the edges and heavily reticulated at the haft; bright yellow beard. An exceedingly tall grower, reaching over 54 inches in height. When well done this is about the most delicately beautiful of all Irises.

$\$ 3.00$ each.

ATHENE (Sturtevant 1918). A vigorous growing, warm white of fine substance and form. The haft is yellowish, veined maroon at the base; beard white. 36 inches. $50 \mathrm{cts}$. each; $\$ 1.25$ for $3 ; \$ 4.00$ per doz.

ATLAS (Millet 1903) 7.5. A bicolor, Bradley's violet with darker velvety veins; haft white. Stalks low and well branched; growth vigorous. 36 inches.

50 cts. each; $\$ 1.25$ for $3 ; \$ 4.00$ per doz.

AUREA (Jacques 1830) 7.4. A yellow self. Empire-yellow with faint brownish veins that make the falls look lighter; orange beard. An old yellow Iris that is hardly surpassed by any of the newer ones. 30 inches.

$35 \mathrm{cts}$. each; $85 \mathrm{cts}$. for $3 ; \$ 3.00$ per doz. 
AUTUMN KING (Sass). A blue-purple bicolor of fine size, shape and height that has a habit of blooming a second time in autumn in some localicies.

$\$ 3.00$ each.

AVALON (Sturtevant 1918) 8.7. A satiny, pinkish-lavender of fine shape and substance. Growth strong but slow, over 36 inches. $\$ 5.00$ each.

A. W. BLAKELY (Fryer 1919). S. yellow, tinted with pink; F. yellow with a dividing line in the center, bordered lighter. 28 inches.

$35 \mathrm{cts}$. each; $85 \mathrm{cts}$. for $3 ; \$ 3.00$ per doz.

AZULADO (Mohr 1924). Sister Seedling of Argentina. Huge flowers of lustrous pearl-gray-blue. Has proved perfectly hardy in the East.

$\$ 5.00$ each.

AZURE (Bliss 1918) 8.0. Beautiful, clear, intense coloring. S. lavenderblue; F. rich violet-blue. A bicolor of the type of Perfection and B. Y. Morrison. 36 inches.

$50 \mathrm{cts}$. each; $\$ 1.25$ for $3 ; \$ 4.00$ per doz.

BALBOA (Mohr 1923). A large, tall, bright red-violet bicolor. Fine, distinct flowers of good substance, borne on stout stems. A Parisiana X Mesopotamica Seedling that has proved hardy in the East. First-Class Certificate from the Massachusetts Horticultural Society. $\$ 2.50$ each.

BALDER (Goos \& Koenemann). S. yellow-olive, with light blush reflex; F. dark reddish-purple. A flower of good form and strong coloring that is sure to prove popular.

$\$ 3.00$ each.

BALLERINE (Vilmorin 1920) 9.4. One of the very finest lavender bicolors. S. broad and waved at the margins, of light blue-violet; F. a deeper blue. Very sweet scented flower, of large size, on stems 48 inches call. A really grand variecy.

$\$ 1.00$ each.

BANDOLLERO (Mohr 1926). A sister Seedling of Alvarado. The flowers are of a distinctive lighe blue, beautifully veined. $\$ 2.50$ each.

BARONET (Sturtevant 1920) 8.0. A Caterina Seedling of a distinct blue tone. S. chickory-blue; F. violet-blue, deepening below the beard. Stalk well branched, over 36 inches.

$\$ 1.00$ each.

BARRELANE (Sturtevant 1921). A blue-toned lavender self with a redviolet flush on the falls. 48 inches.

50 cts. each; $\$ 1.25$ for $3 ; \$ 4.00$ per doz.

BASHI-BAZOUK (Sturtevant 1910). S. light lavender-violet; F. darker violet. A large, loose flower. 42 inches.

50 cts. each; $\$ 1.25$ for $3 ; \$ 4.00$ per doz.

BEAU IDEAL (Sass 1923). A very fine, large Plicata of much substance and good shape. White, with a wide border of petunia violet. 33 inches.

$\$ 2.50$ each.

BELISAIRE (Cayeux 1924). S. soft tan; F. light mulberry-purple. A large, well-shaped flower of the Isoline type that grows on tall, strong scems. A tan coloring that is greatly admired. Considered by many of the most exacting critics to be one of the best of the newer introductions from abroad. Originally named Figaro.

$\$ 10.00$ each.

BELLORIO (Mohr 1924). A very distinct flower of mouse-gray, not large but well placed on 30-inch, branched stems. Absolutely distinct in its soft, subdued colorings. A Korolkowi X Germanica cross. $\$ 2.00$ each.

BENBOW (Bliss 1917) 7.9. S. and F. deep violet-blue. Large blooms on call, erect, well-developed stems. 36 inches.

50 cts. each; $\$ 1.25$ for $3 ; \$ 4.00$ per doz. 
BIANCA (Millet 1912). S. lemon-yellow; F. cream-white, heavily striated mahogany, shading to violet with a yellow piping. Very free flowering and of great vigor. 30 inches. $\quad \$ 1.00$ each; $\$ 2.50$ for 3 .

BLACK PRINCE (Perry 1900) 7.7. A very late variety with a peculiar dark coloring. S. deep violet-purple; F. blackish-purple. The darkest of all Irises in color. The roots of this variety are always small. 30 inches.

$\$ 1.00$ each.

BLUET (Sturtevant 1918) 7.2. A self-colored pale blue that makes a fine, clear mass effect. Good form and substance. 24 inches.

50 cts. each; $\$ 1.25$ for 3.

BOSNIAMAC (Willmott about 1905). Intermediate. Silvery white, shaded primrose.

35 cts. each; 85 cts. for $3 ; \$ 3.00$ per doz.

BRANDYWINE (Farr 1920) 9.1. S and F. light hyssop-violet, indistinctly reticulated gray to olive at the haft; conspicuous red-orange beard. Foliage markedly short. 30 inches

$\$ 2.00$ each.

BRAVURA (Mohr 1926). Flowers of deep, rosy lilac on stout stems. 42 inches.

$\$ 2.50$ each.

BRUNO (Bliss 1922). S. bronze, tinted and lighted with lavender, shading to yellow at the base; F. deep, rich, velvety red-purple. A Dominion Seedling of large size and rich, velvety texture. One of the best of the Dominion Seedlings as we yet know them in America. \$15.00 each.

B. Y. MORRISON (Sturtevant 1918) 8.5. S. pale lavender-violet; F. velvety raisin-purple, widely bordered with lavender. A slow grower until well established; strong, with distinctly slender stalk and foliage. 33 inches.

$\$ 1.00$ each.

CANARY BIRD (Perry). Intermediate. Large, self-colored flowers, strawyellow with a few thin lines. Free flowering and very showy in group plantings. 16 inches. $25 \mathrm{cts}$. each; $60 \mathrm{cts}$. for $3 ; \$ 2.00$ per doz.

CANDELABRE (Vilmorin 1911). An early-flowering variety, with medium-sized flowers. S. broad, white, washed and spotted with violet; F. self violet-brown; beard yellow.

50 cts. each; $\$ 1.25$ for $3 ; \$ 4.00$ per doz.

CANOPUS (Bliss 1919). S. reddish-violet; F. rich pansy-violet, with heavy reticulations at the haft; base of petals stained olive and speckled purplishbrown. Strong, branching spikes; tall and free blooming. A Dominion Seedling that is described as a better Alcazar.

$\$ 3.00$ each.

C. A. PFEIFFER (Fryer 1919). S. blue; F. pansy-violet, with lighter edges; beard light orange; very fragrant.

35 cts. each; 85 cts. for $3 ; \$ 3.00$ per doz.

CAPRICE (Vilmorin 1904) 7.5. A self-colored flower with S. Phloxpurple, and F. slightly deeper in color, shading to bluish-white at the haft, heavily veined. Flowers medium-size, freely produced on short, well-branched stalks. 24 inches. A distinctive grape fragrance.

25 cts. each; 60 cts. for $3 ; \$ 2.00$ per doz.

CARDINAL (Bliss 1919). A Dominion Seedling that has proven to be the most popular of all that group, as it grows in this country. S. a distinctive shade of lavender, overlaid with rose, erect and arching inward at the top; F. rich raisin-purple, very broad and rounded, and of wonderful, glossy texture. A rich, bright Iris that gives a wonderful color effect with transmitted light.

$\$ 20.00$ each. 
CARMELO (Mohr 1923). An unusual and interesting Seedling of Korolkowi X Germanica Major parentage that has proved as hardy as it is graceful and lovely. The long, narrow flowers are a distinct shade of blue-violet with deeper blue veinings, identical in shape with the Korolkowi species. Award of Merit, 1924, by the Royal Horticultural Society, London.

$\$ 1.50$ each.

CATERINA (Foster 1909) 8.9. A delightful shade of soft lavender-blue. Large well-buile flowers of great texture on stout, branching stems. A very handsome variety and a parent of many of the best later introductions. 48 inches.

50 cts. each; $\$ 1.25$ for $3 ; \$ 4.00$ per doz.

CECILE MINTURN (Farr 1922). S. and F. a uniform shade of soft catcleya-rose. Large dome-shaped flowers with light beards very freely produced on strong stems. Strong grower and a rapid multiplier. The best and largest pink-toned variety available for mass plantings.

75 cts. each; $\$ 2.00$ for $3 ; \$ 6.00$ per doz.

CELESTE (Lemon 1855) 7.1. An open-shaped flower of delicate, light color. S. and F. pale verbena-violer, with suggestions of clean white throughour; haft finely reticulated, dusky auricula-purple; beard whice and conspicuous. Growth vigorous; stalks high branched. 30 inches. $25 \mathrm{cts}$. each; 60 cts. for $3 ; \$ 2.00$ per doz.

C. E. STRINGER (Sass 1925). A large, self-colored flower of delicate, light pink, lighter than Dream. A strong, vigorous plant and a free bloomer. 30 inches.

$\$ 4.00$ each.

CHASSEUR (Vilmorin 1923). One of the outstanding yellow varieties that has received high honors abroad. The flowers are large, with broad standards and well-rounded falls of clear, deep yellow, shaded lighter at the center of the falls and marked purplish-red at the base. 36 inches. Considered very fine for garden effect.

$\$ 2.50$ each.

CHERUBIM (Vilmorin 1911) 6.8. A delicately-colored blended self. Palest hortense-violet, flushed pale colonial-buff; F. sparsely veined raisin-purple. 36 inches. Similar in coloring to Wyomissing.

25 cts. each; 60 cts. for $3 ; \$ 2.00$ per doz.

CHESTER HUNT (Farr 1913) 6.9. A strong, vigorous bicolor of decidedly blue tone. S. light wisteria-violer; $F$. veined and shaded a deeper Bradley's violet. 33 inches. $35 \mathrm{cts}$. each; $85 \mathrm{cts}$. for $3 ; \$ 3.00$ per doz.

CLARENCE WEDGE (Fryer 1919). S. heliotrope, tinged with yellow, with lighter edge; F. red-purple, margined bronze-yellow and veined white at the haft. Light cencer line divides the fall, one half of which is shaded darker than the other. Conspicuous orange beard.

$35 \mathrm{cts}$. each; $85 \mathrm{cts}$. for $3 ; \$ 2.00$ per doz.

CLARIDAD (Mohr 1926). A new lavender self of unusual purity of color. The medium-sized flowers have horizontal falls of fine form.

$\$ 2.00$ each.

CLEMATIS (Bliss 1917) 7.8. A unique flower that is aptly named. All six segments reflex horizontally like a Japanese Iris, or a six-peraled clematis. Light lavender-violet, both standards and falls veined darker at the haft. Strong growing, free flowering and fragrant. 30 inches.

$50 \mathrm{cts}$. each; $\$ 1.25$ for $3 ; \$ 4.00$ per doz.

CLUNY (Vilmorin 1920) 8.6. S. wisteria-violet; F. soft bluish-violet, evenly marked purple-brown on a cream ground at the haft and extending below the bright orange beard. A tall-growing variecy, with large flowers that bloom early. 48 inches. 60 cts. each; $\$ 1.50$ for $3 ; \$ 5.00$ per doz. 
COLIAS (Williamson 1925). A call, opaque yellow variety that carries well. Flowers of good size and practically self colored, the falls being only a slightly lighter shade than the standards. A variety of dependable growth and of discince garden value. 36 inches.

$\$ 1.00$ each.

COLONEL CANDELOT (Millet 1907) 8.0. A charming Iris with medium sized flowers of striking color. S. bronze, overlaid reddish-lavender; F. rich, dark, velvety crimson, slightly reticulated white at the throat. Growth slender but strong, with stalks well branched. 33 inches. Color redder than Prosper Laugier and lighter than Ântonio.

60 cts. each; $\$ 1.50$ for $3 ; \$ 5.00$ per doz.

CONQUISTADOR (Mohr 1923). A very tall, vigorous plant with fine foliage and very large flowers of the Lord of June type. Juniata X Mesopotamica parentage. S. lavender-violet, broad and erect; F. a deeper shade of almost madder-violet, long and drooping; haft reticulated dull olive to reddish-brown. This variety has proved hardy here in New York State.

$\$ 3.00$ each.

CORA (Millet). S. violet to purple, tinted bronze at the base; F. deep violet with white markings at the base.

35 cts. each; 85 cts. for $3 ; \$ 3.00$ per doz.

CORONADO (Mohr 1925). S. lavender; F. red-purple, paling to lavender margins; beard and style-arms golden yellow. A fine flower of Eldorado $\mathrm{X}$ Mesopotamica parentage that is in the class with Asia and has better substance.

$\$ 3.50$ each.

CORRIDA (Millet). A charming sky blue self of most delicate and gracefull habits. S. light violet-blue; F. a slightly deeper shade. The flowers are medium size, but of perfect form with erect, lightly frilled standards and straight-hanging falls. Very free flowering and lace. 42 inches.

$50 \mathrm{cts}$. each; $\$ 1.25$ for $3 ; \$ 4.00$ per doz.

CRETONNE (Bliss 1919) 8.4. S. pale bronze-purple; F. rich red-maroon, with a striking orange beard. A strong grower with branching stems, bearing flowers of medium size. 36 inches.

50 cts. each; $\$ 1.25$ for $3 ; \$ 4.00$ per doz.

CRIMSON GLOW (Perry 1925). A beautiful, new variety with wellformed flowers of Aphrodite coloring. A uniform phlox-purple self with standards frilled and incurved and falls exceptionally broad and lightly veined at the haft, bearing a call, orange beard. Vigorous and free flowering on stout, well-branched stems.

$\$ 10.00$ each.

CRUSADER (Foster 1913) 8.7. S. clear, light blue-violet; F. a deeper shade of blue-violet. Large flowers of exceptional substance that withstand the weather well. Slow grower, with tall, erect stems that branch well. 36 inches. One of the finest lavender-blue varieties. Prefers a dry, welldrained location.

$\$ 1.00$ each; $\$ 2.50$ for 3 .

DALILA (Denis 1914) 8.0. A charming litcle flower of clear, pleasing coloring, and desirable habits. S. creamy yellow; F. plum-red. Vigorous and free flowering. 24 inches. The small size of the flowers has undoubtedly cut the rating of this variety. To us, the clear coloring and fine form more than make up for the lack of size. There is a place for small-flowered Irises, and Dalila is just right.

50 cts. each; $\$ 1.25$ for $3 ; \$ 4.00$ per doz.

DALMATICA (Before 1600). Standards and falls clear lavender-blue. One of the best forms of Iris Pallida, having broad, handsome foliage and strong stems. 40 inches. 35 cts. each; 85 cts. for $3 ; \$ 3.00$ per doz. 
DAPHNE (Bliss 1920). A clear-colored amoena that is described as a better Rhein Nixe. S. clear white; F. anthracene-violet, bordered white- a stronger blue than the reddish-purple of Rhein Nixe. 36 inches.

$\$ 3.00$ each.

DAWN (Yeld 1911) 7.8. A free-flowering, early variety of heavy substance and vigorous growth. S. and F. pale marguerite-yellow, deepening toward the center; haft veined greenish-bronze and lightened by a conspicuous orange-tipped beard. 27 inches.

35 cts. each; 85 cts. for $3 ; \$ 3.00$ per doz.

DEJAZET (Vilmorin 1914) 8.3. S. dusky rose-orange; F. clear reddishviolet. The flowers are very large, and of a magnificent, rich coloring that is quite distinct. Growth vigorous, stems short and closely branched. 18 inches.

50 cts. each; $\$ 1.25$ for $3 ; \$ 4.00$ per doz.

DELICATISSIMA (Millet 1914) 8.2. S. lobelia blue, clouded rose; F. companula-violet, shading to lilac-a beautiful, delicate pinkish coloring that is most pleasing. Fine, broad foliage and strong stems. 36 inches.

$\$ 1.00$ each.

DIADEM (Bliss 1919). S. pale mauve; F. deep reddish-mauve; beard brilliant orange. A strong grower on stout stems. 42 inches.

$\$ 1.00$ each; $\$ 2.50$ per 3.

DIMITY (Bliss 1919). S. white, slightly veined and penciled mauve; F. wide, long and spreading, finely veined with lavender toward the upper half; beard white, tipped brown. A distinct variety of soft coloring that is very beautiful as a cut flower. 36 inches.

$60 \mathrm{cts}$. each; $\$ 1.50$ for $3 ; \$ 5.00$ per doz.

DOMINION (Bliss 1917) 9.1. S. light bluish-violet, or Dauphin's blue; F. deep, rich indigo-purple. This remarkable Iris is of particular interest because it marks a distince advance in Iris breeding and is the forerunner of the new race of Dominion Seedlings that show qualities in form and substance heretofore unknown in lrises. The standards are large, erectly held and slightly veined; the falls are spreading and widen out at the base to well-rounded form and are of wonderful, rich, velvety substance. The plant is strong and vigorous, but rather dwarf, and is slow to establish itself when moved. The stalk is strong and upright, closely branched. 30 inches.

$\$ 8.00$ each.

DORA LONGDON (Bliss 1918) 7.8. A richly-colored Iris. S. delicate lavender, suffused yellow; F. rich, red lilac, paling to yellow at the base and on the edges, with heavy brown reticulations at the haft; beard conspicuous bright orange. Height 36 inches. Vigorous growing and free flowering. Very pleasing in massed garden effect.

60 cts. each; $\$ 1.50$ for $3 ; \$ 5.00$ per doz.

DR. ANDRIST (Fryer 1919). S. bronze-yellow; F. velvety maroon-red; orange beard. Delightfully fragrant.

35 cts. each; 85 cts. for 3 ; $\$ 3.00$ per doz.

DR. BERNICE (1867) 7.4. A blended bicolor in rich shades of brown. S. honey-yellow, shading to mikado-brown at the tips; F. velvety burntlake, running into Indian red veins on the yellowish haft. A vigorous variety with stalks well branched. 24 inches.

$35 \mathrm{cts}$. each; $85 \mathrm{cts}$. for $3 ; \$ 3.00$ per doz.

DR. MANTOR (Fryer 1919). S. light coppery-crimson; F. maroon, bordered bronze-yellow, reticulated white and yellow nearly the entire length; beard orange, fragrant.

35 cts. each; 85 cts. for $3 ; \$ 3.00$ per doz. 
DRAKE (Bliss 1919) 8.2. A free-flowering Pallida, with well-shaped flowers of soft violet-blue. A fine garden variety of tall, vigorous growth. 36 inches.

$60 \mathrm{cts}$. each; $\$ 1.50$ for $3 ; \$ 5.00$ per doz.

DREAM (Sturtevant 1918) 8.5. A tall-growing variety of graceful Pallida habits. Soft, clear rose-pink, almost the same shade as Susan Bliss but without the orange beard. Vigorous in growth and a free bloomer, with flowers of medium size and very fine form. Fragrant. 40 inches. The many introductions of "improved" pinks have increased the appreciation of this beautiful variety and it is now in great demand.

$\$ 1.00$ each; $\$ 2.50$ for 3 .

DU GUESCLIN (Bliss 1921) 8.3. S. clear violet-blue, of good shape; F. broad, nicely shaped, bright violet-purple. Best described as a blue Monsignor. Vigorous in growth, and free flowering. 30 inches.

$75 \mathrm{cts}$. each; $\$ 2.00$ for $3 ; \$ 6.00$ per doz.

DUKE OF BEDFORD (Bliss 1922). The general effect in the border is deep violet with a shade of red throughout, the standards being deep violet, the falls of a far deeper tone, almost black-purple in certain lights, with a reddish sheen under violet veins. Like the other Dominion Seedlings, it possesses wonderful velvety texture in the falls. 36 inches.

$\$ 15.00$ each.

DUKE OF YORK (Perry 1925). A giant flower of perfect shape and heavy texture, standing well over 48 inches high. S. broad, soft mauve-blue, faintly stained bronze; F. soft mauve-blue, conspicuously lightened by a bold orange beard.

$\$ 3.50$ each.

DULCINEA (Mohr 1925). A lovely Caterina X Trojana cross with unusually low and wide-branched stems and large, shapely flowers. S. lavender; F. violet-blue with lavender margins.

$\$ 2.50$ each.

DUSK (Morrison 1920) 8.7. An exceptionally fine variety in the same class as Ambassadeur. S. lavender; F. velvety-maroon purple, enhanced by a glow of orange from the center. 48 inches.

$\$ 4.00$ each.

EDEN PHILPOTTS (Perry 1921). Large, well-shaped flowers of a pretty, uniform shade of dark lavender-blue, relieved by a bold white and yellow beard, produced very freely on wide-branching stems. Early.

$\$ 1.50$ each.

EDOUARD MICHEL (Verdier 1904) 8.6. A beautiful flower of distinct, bright, deep petunia-violet, the falls slightly deeper toned than the standards; both $S$. and $F$. gracefully ruffled. 30 inches. When well grown, this flower shows class by its graceful form and refined finish that marks it one of the true "aristocrats." 50 cts. each; $\$ 1.25$ for $3 ; \$ 4.00$ per doz.

EGLAMOUR (Hort 1921). A very large and well-formed purple bicolor that is vigorous and sturdy, with very stout, stiff stems. Rated abroad as one of the best Irises.

$\$ 5.00$ each.

E. H. JENKINS (Bliss 1919). S. pale steel-blue-purple; F. a deeper shade. A fine, vigorous plant, with stout, branching stems. Very free flowering. 45 inches.

$\$ 1.00$ each; $\$ 2.50$ for 3 .

EL CAPITAN (Mohr 1926). A majestic manganese-violet bicolor with wide, flaring falls. It has an extended season of bloom. Tall and vigorous in growth, it is one of the most conspicuous plants in the garden. An Oriflamme X Mesopotamica Seedling that has been rated 9.5 and given an Award of Merit at a University of California show.

$\$ 7.50$ each. 
ELDORADO (Vilmorin 1910) 7.8. A blend of distinct, rich coloring; vigorous and free flowering. S. yellowish-bronze, beautifully shaded with heliotrope; F. bright petunia-violet, touched down the sides with the bronze-yellow of the haft; prominent rich, yellow beard. Striking in color effect but lacking in its habits of growth. 30 inches.

35 cts. each; 85 cts. for $3 ; \$ 3.00$ per doz.

ELIZABETH. S. white, heavily-shaded lilac; F. white, shaded violet at the margins.

25 cts. each; 60 cts. for $3 ; \$ 2.00$ per doz.

EMPIRE (Sturtevant 1918) 7.5. S. and F. clear empire-yellow. A free and dependable bloomer. 30 inches.

35 cts. each; 85 cts. for $3 ; \$ 3.00$ per doz.

ESPLENDIDO (Mohr 1924). A fine, rich red-purple bicolor of large size, with beautifully branched stems. A Mesopotamica X Parisiana Seedling.

$\$ 3.00$ each.

FAIRY (Kennicott 1905) 8.0. A dainty, white Plicata, delicately bordered and suffused soft blue. Early and free flowering on tall, strong stalks. 40 inches. Deserves a place in every garden on account of its delightful fragrance. $\quad 25 \mathrm{cts}$. each; $60 \mathrm{cts}$. for $3 ; \$ 2.00$ per doz.

FIRMAMENT (Grochner 1920). Intermediate. A large-flowering plant of vigorous growth, two shades of light lavender-blue. 24 inches.

50 cts. each; $\$ 1.25$ for $3 ; \$ 4.00$ per doz.

FLAMMENSCHWERT (Goos \& Koenemann 1920). "Flaming Sword." S. bright yellow; F. velvety brown, with a yellow border. A vigorous and free flowering variety similar to Marsh Marigold, Inca and Maori King. 30 inches.

$\$ 1.00$ each; $\$ 2.50$ for 3 .

FLAVESCENS 7.0. The common, early-blooming, pale-yellow Iris. Very pretty in combination plantings with the light blues. 24 inches.

$25 \mathrm{cts}$. each; $60 \mathrm{cts}$. for $3 ; \$ 2.00$ per doz.

FLORENTINA ALBA 7.6. The early May-flowering white, flushed lavender, that blooms along with Kochi. Free blooming. 24 inches. The Fleur-de-lis of literature. $25 \mathrm{cts}$. each; $60 \mathrm{cts}$. for $3 ; \$ 2.00$ per doz.

FOLKWANG (Goos \& Koenemann). S. light rose-pink; F. claret-red, with conspicuous veinings of brownish-yellow, edged light-a beautiful color blending, hard to describe. 24 inches.

$\$ 2.00$ each.

FORSETE (Goos \& Koenemann). A dark lavender self of Pallida type. Strong, vigorous plant with unusual branching stems. 36 to 48 inches.

$\$ 2.00$ each.

FRIEDA MOHR (Mohr 1926). The description of light pinkish-lilac standards and deep lilac-rose falls gives but little idea of the attractive qualities of this flower. In size, shape, substance, and brilliancy of color it is claimed to be an advance over all earlier pink bicolors. The available stock is as yet very scarce.

$\$ 25.00$ each.

FRO (Goos \& Koenemann 1910). S. mustard-yellow; F. oxblood-red. A brilliant, high-colored Variegata. Very vigorous and free flowering. 24 inches.

35 cts. each; 85 cts. for $3 ; \$ 3.00$ per doz.

FRYER'S GLORY (Fryer 1919). A beautiful, richly colored flower, after the style of Prosper Laugier, the "Brown Iris." S. golden-bronze, tinged with crimson; F. bright, velvety maroon, heavily striated yellowishwhite from the center to the base; beard orange. Late. 30 inches.

75 cts. each; $\$ 2.00$ for $3 ; \$ 7.00$ per doz. 
GABRIEL (Bliss 1923). A magnificent new novelty with enormous flowers of perfect form and erect carriage. S. bright, clear steel-blue, very broad and rounded, and finely arched; F. light violet-blue, suffused deeper at the haft, as broad as the standards and flat hanging. Very vigorous and strong in growth, with strong, well-branched stems four feet high. Said to be a greatly improved "E. H. Jenkins." \$20.00 each.

GAJUS (Goos \& Koenemann 1906). S. pale yellow; F. heavily-veined maroon-red. A greatly improved Gracchus. 24 inches.

25 cts. each; 60 cts. for $3 ; \$ 2.00$ per doz.

GAVIOTA (Mohr 1924). A creamy-white Plicata, both standards and falls distinctly edged yellow. Medium-sized flowers of unusual color, fine finish and texture. Perfectly hardy in the North.

$\$ 1.50$ each.

GEORGE J. TRIBOLET (Williamson 1926). This magnificent new introduction well depicts the ideals of quality that Mr. Williamson is endeavoring to breed into his Irises-strong and vigorous growth, freedom of bloom, with form and substance rather than size in the flowers. S. Nigrosin-violet; F. a solid and velvety, blackish red-purple, with a coppery suffusion throughout the whole flower that is most effective. The blooms are medium to large in size, of finest form, and are borne freely on well-branched stalks 40 inches tall. A distinct and beautiful Iris when judged as a single flower, as a separate stalk of bloom, or as a flowering clump.

$\$ 6.00$ each.

GEORGE YELD (Perry 1923). S. bright apricot, shaded rose; F. brilliant rose-crimson, edged buff. Large flowers of fine form, produced on tall, strong, well-branched stems. This beautiful variety, named in honor of the president of the English Iris Society, is reputed in England to be very fine, and is considered to be one of Perry's best Irises. The color combination is novel, distinct and beautiful.

$\$ 7.50$ each.

GEORGIA (Farr 1920) 8.9. S. and F. a uniform shade of soft catcleya-rose, with a brilliant orange beard. Early, bright, free-flowering and vigorous. 24 inches. One of the best pink varieties, of value because of its early flowering.

$\$ 1.00$ each; $\$ 2.50$ for 3 .

GERALDINE (Yeld 1911). S. white, tinted lavender; F. richly reticulated purple on a white ground; very bright orange beard. 48 inches. $\$ 1.50$ each.

GERMAINE PERTHUIS (Millet 1924). A descendant of Mme. Gaudichau that has inherited all the good qualities of its parent-exceptional vigor, good habits, and great freedom of bloom. S. a pleasing shade of violet-purple, lighted with a lighter tone; F. deep, rich Bishop's violet, lighted by a prominent yellow beard. The whole flower is of unequaled velvety appearance and is deliciously scented. 36 inches. This variety was considered the outstanding new variety to bloom in America last season, and it is in great demand.

$\$ 15.00$ each.

GERTRUDE (Peterson 1907) 6.5. A blue-purple self of Pallida form that is early, free-flowering, and vigorous. 36 inches. This is a better Iris than its rating would indicate, and is the most satisfactory deep blue of all the earlier introductions. $25 \mathrm{cts}$. each; $60 \mathrm{cts}$. for $3 ; \$ 2.00$ per doz.

GLAMOUR (Bliss 1922). This Dominion Seedling has all the good qualities of the parent - richness of color, heavy substance and fine form. In addition, it is strong and better branched in its growth and is particularly free flowering. The individual blooms are not quite as large as those of Moa or Titan but have great lasting quality and refinement. The broad and finely-arched standards are light lobelia-violet, shaded vinaceous buff at the edges; the falls rich, velvety blackish-purple, shading lighter at the borders; beard yellow-orange. 36 inches. $\$ 15.00$ each. 
GOLDEN FLEECE (Caparne). Early, large-flowered. One of the best of the light yellow Irises. 25 cts. each; 60 cts. for $3 ; \$ 2.00$ per doz.

GOLDEN PLUME (Fryer 1919). S. rich golden-yellow; F. chestnutbrown, edged and reticulated yellow; yellow beard. Equally as thrifty as the well-known Honorabilis and a few inches taller.

$25 \mathrm{cts}$. each; 60 cts. for $3 ; \$ 2.00$ per doz.

GOLD IMPERIAL (Sturtevant 1924). A yellow self of wonderful, bright, clear coloring. S. and F. empire to lemon chrome yellow throughout; beard conspicuous, orange. A medium-sized flower of ideal form borne on a vigorous plant. 36 inches. A real yellow Iris, deeper and more uniform in color than Shekinah, and darker than Primrose.

$\$ 6.00$ each.

GOV. HUGHES (Fryer 1919) 7.1. S. violet, tinged red; F. darker shade of the same color, veined brown; very heavy, orange beard. Extremely free flowering and excellent for mass plantings.

25 cts. each; 60 cts. for $3 ; \$ 2.00$ per doz.

GRAPTA (Williamson 1925). Standards of yellowish or toast brown; falls deeper, heavily reticulated yellow toward the base. Flowers of medium size on stems of 24 inches. Early midseason. This distinct flower has been aptly described as "molasses colored."

$\$ 1.00$ each.

GREVIN (Vilmorin 1920) 8.5. S. arched, bright violet, tipped yellowishbrown; F. rich, velvety violet-purple, heavily reticulated brown at the haft. A good dark-toned flower of great substance. Fragrant. Late flowering. 24 inches.

$75 \mathrm{cts}$. each; $\$ 2.00$ for 3 .

G. W. PEAKE (Fryer 1919). S. yellow, shaded crimson-bronze, lighter yellow at the base; $F$. velvety maroon-red, edged with bronze-yellow, reticulated at the base; conspicuous orange beard; fragrant.

35 cts. each; $85 \mathrm{cts}$. for $3 ; \$ 2.00$ per doz.

HARRIET PRESBY (Presby 1922). S. bright violet; F. petunia-violet; haft finely reticulated orange-apricot; beard white, tipped orange. The general effect is soft, light reddish like the coloring of a cattleya orchid. Tall and vigorous in growth. 36 to 48 inches.

$\$ 2.00$ each.

HAUTEFEUILLE (Denis 1910) 7.4. A tall, vigorous variety of medium size borne on very tall stems. S. very dark violet; $F$. very deep, velvety reddish-purple. 40 inches. 50 cts. each; $\$ 1.25$ for $3 ; \$ 4.00$ per doz.

HERMIONE (Hort 1920) 8.8. A large, late-flowering bicolor of exceptionally fine form and substance. S. lavender-violet; F. flushed hortense-violet below the thick, yellow beard; haft conspicuously edged yellow ochre to ochraceous tawny. Foliage markedly broad and short; stalks well and widely branched. 36 inches.

$\$ 3.00$ each.

HESPERIA (Williamson 1926). A large and striking bicolor of distinct coloring of the same light brown effect as Nibelungen, but larger and of heavier substance. S. light drab; F. a solid, blackish red-purple, flushed amber. 36 inches. A strong-growing and free-flowering variety.

$\$ 2.50$ each.

HIDALGO (Mohr 1925). A very large, lavender self of unusually broad shape; call and upstanding.

$\$ 3.50$ each.

HUBERT (Hort 1921). A rich self, Bradley's to Dauphin's violet. The flower is not large but is distinct by reason of the brilliant yellow beard that extends half the length of the falls. 30 inches.

$\$ 2.00$ each. 
IGNACITE (Lemon 1859). An old and robust variety that is reliable under all conditions. S. and F. light blue, with faint veinings that deepen toward the haft. 30 inches. $25 \mathrm{cts}$. each; $60 \mathrm{cts}$. for $3 ; \$ 2.00$ per doz.

IMPERATOR (Cayeux 1923). Very large, late-flowering bicolor with cupped standards and straight-hanging falls of Marhew's to raisin-purple, shading white at the haft with heavy red-brown reticulations. A strong, vigorous plant with strong stems. 40 inches. The coloring is similar to Edouard Michel but more reddish-bronze, duller than Seminole.

$\$ 4.00$ each.

INCA (Farr 1922). S. clear, deep saffron-yellow; F. velvety, dark plum, with edges and medial line of gold, and reticulated gold at the base. One of the most brilliant Irises that might be described as a taller and more brilliant Pfauenauge. 24 inches.

75 cts. each; $\$ 2.00$ for $3 ; \$ 6.00$ per doz.

IRIS KING (Goos \& Koenemann 1907) 7.9. A large, well-formed flower of very rich coloring. S. buff-yellow, arching; F. very broad and flaring, velvety garnet-brown, shaded oxblood-red and bordered with yellow; haft yellow. Moderate grower, with high-branched stalks. 24 inches. This grand Iris, though not highly rated, is included in the list of almost every Iris authority as the best of its color type.

35 cts. each; 85 cts. for $3 ; \$ 3.00$ per doz.

ISOLENE (Vilmorin 1904) 8.6. A grand, distinct Iris with very large flowers and strong foliage. S. lilac-pink; F. purplish old-rose, golden at the throat; beard yellow. The straight-hanging falls give the flower a long appearance. On established clumps it flowers freely on strong, well-branched stems. Among all the newer introductions it still holds its place as a distinct and worthy flower. 36 inches.

35 cts. each; 85 cts. for $3 ; \$ 3.00$ per doz.

IVANHOE (Millet 1911) 8.3. S. light lavender-violet, passing to yellow at the base; F. Dauphin's violet, reticulated purple-brown at the haft; beard orange. 36 inches. $50 \mathrm{cts}$. each; $85 \mathrm{cts}$. for $3 ; \$ 4.00$ per doz.

JACQUESIANA (Lemon 1840) 8.0. S. bronzy lilac-red; F. flaring, rich purple-red. An old variety that is still a favorite. 36 inches.

$35 \mathrm{cts}$. each; $85 \mathrm{cts}$. for $3 ; \$ 3.00$ per doz.

JAPANESQUE (Farr 1922). S. lavender-white, flecked violet; F. deep violet, edged pale lavender; beard coppery yellow. The six petals, spreading horizontally in the form of a Japanese Iris, give the flower the effect of having six falls and no standards.

50 cts. each; $\$ 1.25$ for $3 ; \$ 4.00$ per doz.

JEAN CHEVREAU (Cayeux 1923). S. primrose-yellow to olive-buff, sanded at the center with mauve; F. cream, stippled and edged Prussianred at the haft; beard dense yellow. The flowers are medium size, freely borne on a vigorous plant. 30 inches. A Plicata blend in a class with Loudoun and Mme. Chobaut that is very beautiful and pleasing.

$\$ 5.00$ each.

JEANNE D'ARC (Verdier 1907) 7.8. S. and F. white, edged lavender. A dainty Plicata that is better than Mme. Chereau and very close to Ma Mie and Anna Farr. 30 inches.

25 cts. each; 60 cts. for $3 ; \$ 2.00$ per doz.

JENNETT DEAN (Sturtevant 1920). Deliciously fragrant blossoms of soft, iridescent lavender-violet. A very large flower with flaring falls; stalk low and widely branched. Over 36 inches. $\$ 5.00$ each. 
J. J. DEAN (Dean 1922). S. light violet; F. velvety royal-purple. A handsome large flower and a tall grower.

$\$ 1.00$ each.

JUBILEE (Sass 1923). A distinct and beautiful Plicata of buff tone. S. and F. light buff, heavily margined with flecks of dark copper. A finished flower of fine form that is much admired by all who see it.

$\$ 5.00$ each.

JULIA MARLOWE (Shull 1924). S. Chinese-violet; F. raisin-purple. Very large flower with tall, arched standards and long, straight-hanging falls of Magnifica shape. The coloring produces a rich, glowing pinkand-red effect in the sun similar to Leverrier. The stalk is tall and well branched. Fragrant. 40 inches.

$\$ 7.50$ each.

JUNIATA (Farr 1909) 8.1. S. and F. clear blue-violet, deeper than Dalmatica, with bright orange beard. A tall, fine plant producing large flowers that are sweetly scented. The foliage is distinctively long and drooping. 42 inches. $\quad 35$ cts. each; 85 cts. for $3 ; \$ 3.00$ per doz.

JUNONIA (Species). S. soft blue; F. violet-blue-purple. A flower of good substance that resists the sun well, making a desirable plant for landscape use. 42 inches.

$75 \mathrm{cts}$. each.

KASHMIRIANA (Species). White, slightly-washed lavender. Petals of stout, leathery texture; falls horizontal.

KASHMIR WHITE (Foster 1913). Fine, large, pure-white flowers produced on very tall, strong stems. 48 inches. To do well this variety must have a well-drained location in full sun.

$\$ 1.00$ each.

KATHRYN FRYER (Fryer 1917) 8.1. S. clear straw-yellow; F. velvety maroon-red, veined white at the center and reticulated yellow at the base; beard orange. A late-flowering variety, fragrant, and very floriferous. 36 inches.

$\$ 1.00$ each.

KHARPUT (Species) 7.4. An early-flowering variety collected and named from a town in Mesopotamia. S. pleroma-violet, broad and floppy; F. velvety nigrosin-violet, straight-hanging; beard white, tipped orange. The growth is vigorous with stalks well branched. The young foliage is tinged purple on the edges. 30 inches.

35 cts. each; 85 cts. for $3 ; \$ 3.00$ per doz.

KING KARL (Sass 1924). A beautiful Plicata, deeply frilled and dotted reddish-brown. 30 inches.

$\$ 5.00$ each.

KNYSNA (Bliss 1917). A very fine variety with small blooms but exceedingly free flowering and a vigorous grower. S. long and arching, clear, deep yellow; F. deep, velvety red-brown. 30 inches.

60 cts. each; $\$ 1.50$ for 3.

KOCHI (Species). A wild Iris from southern Europe. Flowers a deep blackish-purple - a rich coloring that is greatly admired. Blooms early, at the same time as Florentina alba, with which it makes a fine planting. 24 inches.

$25 \mathrm{cts}$. each; $60 \mathrm{cts}$. for $3 ; \$ 2.00$ per doz.

LADY BYNG (Bliss 1922). A sister Seedling of Susan Bliss, a beautiful flower of fine form and substance. The color throughout is clear, pale lavender, slightly darker than Mlle. Schwartz, suffused with rose Vigorous in growth, a free bloomer, and increases quickly. 36 inches.

$\$ 3.00$ each.

LADY FOSTER (Foster 1913) 8.5. Large flowers of smooth, heavy texture and fine form. S. pale blue; F. light blue-violet, veined old-gold at the broad throat. 42 inches. A beauty.

$\$ 1.00$ each. 
LADY LOU (Dean 1921). A lavender-violet self of Pallida type, vigorous in growth and of value because of its earliness.

$75 \mathrm{cts}$. each.

LANCELOT (Bliss 1919). A distinct variety bearing well-shaped, selfcolored flowers of pale rosy-mauve, with a bright orange beard. Vigorous in growth with stout stems. 36 inches.

$\$ 1.00$ each.

LA NEIGE (Verdier 1912) 8.3. A fine, pure ivory-white variety with flowers of great substance and fine form. 24 inches.

35 cts. each; 85 cts. for $3 ; \$ 3.00$ per doz.

LEANDER (Bliss 1920). A showy variety of medium growth, with wellshaped, reddish-violet, self-colored flowers of an unusual shade. 30 inches.

$\$ 1.50$ each.

LENT A. WILLIAMSON (Williamson 1918) 9.0. S. very broad, companula-violet; F. broad and drooping, velvety violet-purple; beard yellow. Large flowers of exceptional substance on stout stems. Extremely vigorous in growth. 42 inches.

50 cts. each; $\$ 1.25$ for $3 ; \$ 4.00$ per doz.

LEONATO (Hort 1922). A giant flower on the lines of Lady Foster; very fragrant and exceedingly large, but at the same time shapely and well proportioned. S. pale lavender, passing to silvery-heliotrope in certain lights; F. of slightly darker tone than the standards, widely expanded, $21 / 2$ inches across at the haft, with dark reticulations on a white ground. Early flowering and very strong growing. 48 inches. $\quad \$ 10.00$ each.

LEON TRENANCE (Bliss 1922). An early and an exceptionally freeflowering variety. S. pale lavender; F. slightly darker tone and much reticulated. A vigorous plant with strong, erect stems. 36 inches. Its free blooming and excellent growth make this a desirable Iris for landscape plantings.

$75 \mathrm{cts}$. each; $\$ 2.00$ for 3 .

LEPINOUX (Millet 1923). A Ricardi hybrid. An exceedingly tall plant, with strong, well-branched stems and very large flowers. S. anilineblue; F. deeper, with heavy reticulations on a white ground at the haft. Deliciously scented. 48 to 54 inches.

$\$ 3.00$ each.

LEVERRIER (Denis 1917) 9.0. S. a beautiful shade of mauve; F. rich pansy-violet. Large flowers on a tall, branching stem. One of the finest of the French introductions that has aptly been described as a redder Magnifica.

$\$ 2.50$ each.

LOHENGRIN (Goos \& Koenemann 1910) 8.2. A large self-colored flower of uniform soft cattleya-rose. Vigorous Pallida habits of growth, but not a real free bloomer. 36 inches.

35 cts. each; 85 cts. for $3 ; \$ 3.00$ per doz.

LONA (Sass 1923). A soft, buff, Plicata-type flower, shaded at the margins with purple and enlivened by the yellow haft and beard. A choice and unusual blend. 30 inches.

$\$ 5.00$ each.

LORD LAMBOURNE (Perry 1923). A magnificent Iris with large, wellshaped flowers produced freely on tall, branching stems. S. a delightful shade of rose-fawn, suffused with pale bronze; F. rich madder-crimson, reticulated white at the base and illuminated with a bright yellow beard. 48 inches.

$\$ 6.00$ each.

LORD OF JUNE (Yeld 1911) 9.1. A very handsome Iris of largest size. S. chicory-blue; F. lavender-violet. Vigorous and free flowering. 36 to 48 inches. The immense blooms, with broad, rounded standards and large, drooping falls are carried gracefully on well-branched stems and are most effective eicher in the garden or as a show spike. $\$ 1.00$ each. 
LORELEY (Goos \& Koenemann 1909) 7.9. A very vigorous-growing bicolor that bears its flowers in greatest profusion on strong, upright stems. S. martius-yellow, often splashed with the purple of the falls; F. raisin-purple, margined canary-yellow, with purple reticulations at the haft on a white ground. Foliage tinged purple at the base. Very fragrant. Being an early bloomer with its abundance of flowers extended over a long period, this is a desirable and popular landscape variety.

25 cts. each; 60 cts. for $3 ; \$ 2.00$ per doz.

LOUDOUN (Fendall). A novelty Plicata of unusual and pleasing coloring. S. clear amber-yellow, faincly flecked at the base; F. white, flushed amber at the edges and madder-violet at the haft and on the midrib. Growth vigorous with stalks widely branched. 36 inches. Given Honorable Mention by the American Iris Society in 1924.

$\$ 10.00$ each.

LOUTE (Vilmorin 1904). purple, with bronzy veins.

S. light lilac, flushed bronze; F. reddishA large flower of attractive coloring.

$35 \mathrm{cts}$. each; $85 \mathrm{cts}$. for $3 ; \$ 3.00$ per doz.

LYCAENA (Williamson 1925). A particularly fine Amoena. The flowers are of good shape and the pale, margined falls, of a deep shade of rich purple, are in clean and beautiful contrast to the white standards.

$\$ 1.00$ each.

MADY CARRIERE (Millet 1905) 7.9. So pale plumbago-blue; F. argeratum-blue, shading to rich yellow at the base. A pleasing blend on the order of Afterglow that is very beautiful in mass effect. 30 inches. 75 cts. each; $\$ 2.00$ for 3 .

MAGNIFICA (Vilmorin 1920) 9.1. Very large flowers, borne on tall, stiff, branching stems. S. light violet-blue, very broad; F. long, deep, rich violet-red, reticulated brown at the haft; beard yellow; sweet scented. Over 36 inches.

$\$ 1.00$ each.

MAJESTIC (Bliss 1923). Enormous flowers of finest form, great substance and lasting quality. S. circular and arching, nearly 3 inches broad, light lavender to mauve, stained light bronze at the base; F. straight hanging, smooth and flat, $21 / 2$ inches broad, rich velvety raisinpurple. An exceedingly good-growing plant with stout, branching stems. 42 inches.

$\$ 10.00$ each.

MA MIE (Cayeux 1906) 8.1. A fine, large Plicata with S. and F. clear white, frilled violet-blue. A good, free-flowering Iris, probably the best of the several varieties of Mme. Chereau type. 36 inches.

$35 \mathrm{cts}$. each; 85 cts. for $3 ; \$ 3.00$ per doz.

MANDRALISCAE 7.3. Rich, lavender-purple flowers of Pallida type. A tall, strong grower with 40 -inch flower stalks. Blooms very early.

$25 \mathrm{cts}$. each; 60 cts. for $3 ; \$ 2.00$ per doz.

MAORI KING (Ware 1890). S. rich golden-yellow; F. deep purplemaroon. A vigorous variety of bright coloring. 21 inches.

$25 \mathrm{cts}$. each; $60 \mathrm{cts}$. for $3 ; \$ 2.00$ per doz.

MARGERY (Dean 1922). S. light wisteria-violet; F. Bradley's violet; deep chrome beard. A strong, tall-growing Iris of good quality.

$\$ 3.00$ each.

MARIPOSA (Mohr 1923). A very late-flowering variety from California that is perfectly hardy everywhere. The medium-sized flowers, well poised on fine, branched stems, are pale porcelain-blue, with the falls variably marked with red-purple. 36 inches.

$\$ 1.00$ each. 
MARSH MARIGOLD (Bliss 1919). One of the brightest and most striking of the Variegaras. S. pale golden-yellow; F. deep purple-brown, with a bright yellow margin. Described as a greaty improved Maori King.

$\$ 1.50$ each.

MARY BARNETT (Cumbler 1926). This fine new Iris, grown by Mrs. M. A. Cumbler, has attracted the attention of keen Iris critics for several seasons. It has been thoroughly tested and has proved its worth as a free-blooming, vigorous and reliable flower. It is best described as being a Princess Beatrice with a glorious golden beard, so brilliant that it refleces throughout the flower. We are glad to be able to offer this fine Iris.

$\$ 10.00$ each.

MARY GARDEN (Farr 1913) 7.8. A curiously speckled Plicata that is attractive because it is unusual. S. pale yellow, flushed pale lavender; F. long and drooping, creamy-white, minutely dotted and veined maroon; stigmas clear yellow. 28 inches.

35 cts. each; 85 cts. for $3 ; \$ 3.00$ per doz.

MARY GIBSON (Perry 1923). This beautiful Iris is one of the most distinct yet raised. S. a delicate shade of light bronze, overlaid old-rose; F. old-rose, suffused bronze, with a conspicuous yellow base and bold orange beard.

$\$ 10.00$ each.

MARY ORTH (Farr 1920). S. light blue-violet; F. dark blue-violet. A large dome-shaped flower of good form and color. One of the very best of the Farr Irises. 18 to 24 inches.

$\$ 1.00$ each.

MARY WILLIAMSON (Williamson 1921). S. clear white; F. purple, with a wide white border. The flowers are produced in profusion on slender but strong stems. The plant is robust in growth and is particularly desirable for mass plantings. 30 inches.

$\$ 1.50$ each.

MAUVINE (Dean 1919). S. mauve; F. a few shades darker of the same color. A handsome flower, tall and free flowering.

35 cts. each; 85 cts. for $3 ; \$ 3.00$ per doz.

M. BURN (Denis 1920). A large Ricardi Seedling of very uncommon coloring. S. argeratum-blue, shaded with brown; F. light purple, shaded brown and heavily reticulated brown on a white ground at the haft. The flowers are large and well formed, and the stems well branched. 36 inches. In these Ricardi Seedlings, Mme. Durrand and M. Burn, we have colorings that are distinct and beautiful and they are well worth the extra care required to grow them successfully.

$\$ 7.50$ each.

MEDRANO (Vilmorin 1920) 8.5. A remarkable and fine flower of very distinct coloring. S. reddish-copper, with slight suggestions of violet; $F$. dark crimson-purple, almost black in parts, flecked with buff and lavender. A late bloomer. 30 inches.

$\$ 1.00$ each; $\$ 2.50$ for 3 .

MENTRIER (Denis 1921). A large-flowered variety of Ricardi origin. S. yellow, shaded terra-cotta; F. bronze-yellow, striped maroon on yellow at the haft. A free bloomer. 42 inches.

$\$ 2.00$ each.

MERLIN (Sturtevant 1917) 8.3. A large, pink-toned, violet flower, with cupped standards revealing the buff of the styles. 30 inches. $\$ 1.00$ each.

M. G. PETERS (Fryer 1917). S. yellow, tinged with heliotrope and edged pure yellow; F. violet, shaded with brown, margined light yellow and edged brown, mottled and veined light yellow, and reticulated yellow at the base; orange beard. Large flowers on stout stems.

$35 \mathrm{cts}$. each; $85 \mathrm{cts}$. for $3 ; \$ 3.00$ per doz. 
INDIAN SPRING FARMS, INC.

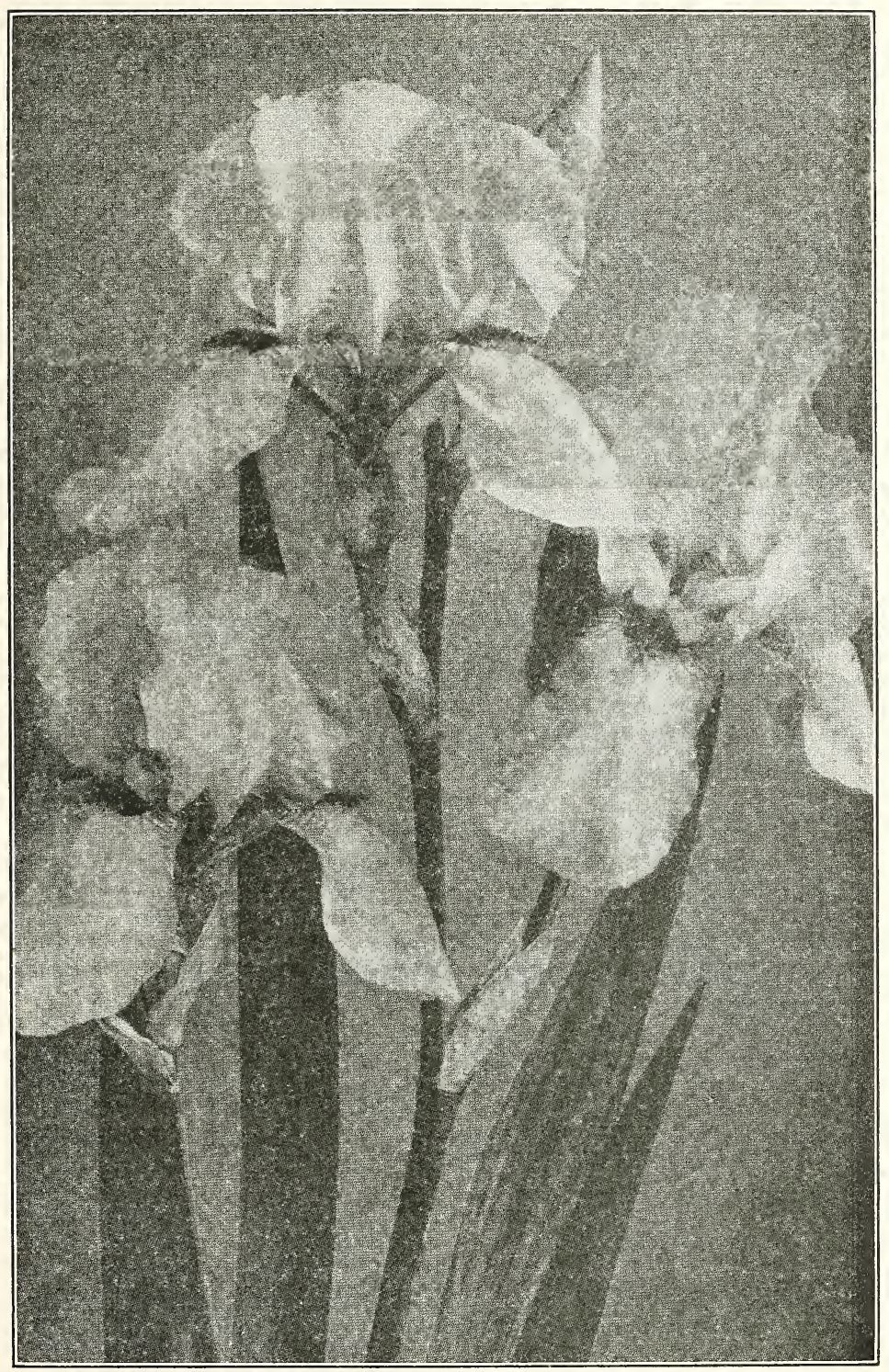

The New Iris, Mary Barnet 
MIDWEST (Sass 1922). A fine ruffled Plicata. S. flushed and dotted Mathew's purple; F. white, heavily bordered the same color. Large flowers of fine form with standards and falls delightfully ruffled. The stalks are low, well branched, and of vigorous growth. 30 inches.

$\$ 1.00$ each.

MILDRED PRESBY (Farr 1923). S. white; F. rich, dark, velvety pansyviolet, with narrow edge of lavender-white. The flowers, of large size and clear colorings, surpass all the other Irises of similar type, both as individual blooms or for garden effect. 30 inches.

$\$ 2.50$ each.

MINNEHAHA (Farr 1913). S. creamy-white, shaded yellow; F. creamywhite, heavily reticulated maroon; stigmas clear yellow. 24 inches.

$35 \mathrm{cts}$. each; $85 \mathrm{cts}$. for $3 ; \$ 3.00$ per doz.

MIRANDA (Hort 1919). A grand Iris that blooms early on a vigorousgrowing plant with strong, well-branched stems. The flowers are nicely formed with arched standards and flaring falls and are uniformly colored dull bluish-violet, with a distinct, metallic sheen that is very beautiful. This is nearest to a true, dark blue Iris, and is proving to be the best in its class. 42 inches.

$\$ 1.00$ each.

MLLE. SCHWARTZ (Denis 1916) 8.7. A large, free-flowering self of finest form. Uniform, soft, light lavender-blue, or mauve, that is distinct, delicate and beautiful. A shade lighter than Mother of Pearl. 48 inches. If given a well-drained location this is a free, robust grower and produces a marvelous garden effect.

$\$ 1.00$ each.

MME. BAZE (Denis 1918). A charming flower of medium size. S. pale whitish-amber, shading to a light argeratum-blue; F. greenish-white, heavily reticulated maroon at the throat; beard white with yellowish tips.

$50 \mathrm{cts}$. each; $\$ 1.25$ for 3.

MME. BOULLET (Denis 1919) 7.7. S. deep colonial-buff, with deep, red edge and brown lines at the base; F. yellow, lined and dotted deep brown; beard yellow, tipped brown. $35 \mathrm{cts}$. each; $85 \mathrm{cts}$. for $3 ; \$ 3.00$ per doz.

MME. CECILE BOUSCANT (Millet 1923). One of the most magnificent Ricardi hybrids in cultivation, of highest standard in form and substance; but like all Ricardis it needs skilled cultivation. The color is a lovely shade of pink, somewhat like Dream, but slightly deeper. Free flowering. 48 inches.

$\$ 7.50$ each.

MME. CHEREAU (Lemon 1844) 7.4. White, elegantly frilled with a wide border of clear blue. An old favorite. 36 inches.

25 cts. each; 65 cts. for $3 ; \$ 2.00$ per doz.

MME. CHERI (Sturtevant 1918) 8.4. Argeratum-violet, washed with pink and warmed by a yellow undertone. The falls slightly darker than the standards. An exquisite blend; tall and vigorous. 48 inches.

$\$ 1.00$ each.

MME. CHOBAUT (Denis 1912) 8.5. S. white, shot with pale chalcedonyyellow, shading to wine-red; F. white, edged with lilac. There is a clean contrast of colors in this unusual Plicata that is most pleasing. 36 inches.

$60 \mathrm{cts}$. each; $\$ 1.50$ for 3 .

MME. CLAUDE MONET (Denis 1912). A very dark hybrid of Ricardi X Kochii of Mme. Gaudichau type. Large flowers of manganese to dull, dusky velvety-purple; haft heavily reticulated auricula-purple. Growth variable with stalks not well branched. 36 inches. Quite rare. 
MME. DURRAND (Denis 1912) 8.6. Large flowers of fine form and a most attractive tan, or buff, coloring. Considered by many to be the most beautiful of all Irises. S. dome-shaped, iridescent cinnamon-buff, flecked lilac; F. flushed with lilac on a ground of old-gold, shading to amber at the throat with reticulations of cinnamon to liver-brown. Growth variable, with stalks widely branched. 60 inches. A Ricardi hybrid that is a slow grower and requires a protected location but is well worth the special care required.

$\$ 4.00$ each.

MME. HENRY CAYEUX (Cayeux 1924). A handsome variety of Ambassadeur type, with very large flowers. S. reddish, slaty violetpurple; velvety, dark reddish-purple, lighter at the edges; beard bright yellow. Strong in growth producing quantities of flowers. 42 inches.

$\$ 10.00$ each.

MOA (Bliss 1920). One of the tallest of the Dominion Seedlings, producing large flowers on stems 40 inches high. S. broad and arching, pure violet; F. circular and flat, deep violet-purple, or pansy-violet. $A$ magnificent Iris that is rated as one of the best in the world. $\$ 15.00$ each.

MOLIERE ${ }^{-}$(Vilmorin 1920) 8.5. S. violet-blue; F. deep, rich, velvety violet, veined brown; beard yellow. A very large flower, equally as fine as Magnifica but on shorter stems. 30 inches.

60 cts. each; $\$ 1.50$ for $3 ; \$ 5.00$ per doz.

MONSIGNOR (Vilmorin 1907) 8.4. A distinct, strong-growing Iris of rich coloring. S. pale violet; F. pale violet ground-color, richly overlaid and veined with deep purple. 24 inches.

$25 \mathrm{cts}$. each; $85 \mathrm{cts}$. for $3 ; \$ 2.00$ per doz.

MONTEZUMA (Farr 1909) 8.3. S. deep golden-yellow, minutely dotted brown; F. yellow and white, veined purple and dotted brown. 18 inches.

50 cts. each; $\$ 1.25$ for 3.

MORNING SPLENDOR (Shull 1923). This is the outstanding Iris of all American introductions today. In 1922 it received Honorable Mention from the American Iris Society, and in 1926 it was awarded the Silver Medal of the Garden Club of America in competitive test at the New York Botanical Garden. The flowers are large, of fine form, heavy substance, and delightful fragrance, and are borne on tall, strong stems. $S$. petunia violet; $F$. rich raisin-purple. When viewed in transmitted sun light, a most beautiful red effect is produced, the most brilliant yet seen in an Iris. 48 inches.

$\$ 5.00$ each.

MORWELL (Bliss 1919) 8.2. A fine, pale blue-purple bicolor of largest size and perfect shape. The coloring is uniform throughout except for reticulations of brown on the broad haft. A little slow to become established but is strong and vigorous-larger and better than Caterina. 30 inches.

$\$ 1.00$ each; $\$ 2.50$ for 3 .

MOTHER OF PEARL (Sturtevant 1921). S. and F. pale bluish-lavender, with a faint creamy undertone. Large flowers of perfect form and exceptional substance that have a distinct luster and iridescence, or pearly effect, from which the flower is so aptly named. The plant is a tall, vigorous grower and a profuse bloomer. $\$ 1.00$ each; $\$ 2.50$ for 3 .

MOUNT PENN (Farr 1919) 8.2. S. lavender-rose; F. crimson-lilac; deep orange beard. A call-growing and free-flowering Iris with flowers of a distinct reddish tone that are especially fine for mass effect.

75 cts. each; $\$ 2.00$ for 3 . 
MRS. ALAN GRAY (Foster 1909) 7.6. A small flower of a soft shade of pinkish-lilac that is very pleasing in mass plantings. Often produces a second lot of flowers in August. 30 inches.

25 cts. each; 65 cts. for $3 ; \$ 2.00$ per doz.

MRS. COWLEY (Bliss 1920) 7.8. S. coppery-buff; F. deep, rosy-purple. A free-flowering variety, striking and beautiful on account of its quiet coloring. 27 inches.

50 cts. each; $\$ 1.25$ for $3 ; \$ 4.00$ per doz.

MRS. EDWARD HARDING (Perry 1925). A very beautiful Pallida variety with large, well-formed flowers of great substance freely produced on strong stems over 54 inches high. S. violet-purple; F. darker violet-purple, overlaid black; beard bronze-yellow.

$\$ 20.00$ each.

MRS. HETTY MASON (Perry 1923). Large, globular flowers, similar in form to Lord Lambourne but of different coloring. S. purple-fawn, shot bronze; F. broad, rich crimson-purple; rich yellow beard. $\$ 5.00$ each.

MRS. HORACE DARWIN (Foster 1888) 6.8. S. snow-white; F. white, slightly reticulated violet at the haft. Very free flowering. 24 inches. $25 \mathrm{cts}$. each; $65 \mathrm{cts}$. for $3 ; \$ 2.00$ per doz.

MRS. MARION CRAN (Perry 1923). A very fine pink Iris that is rated by those who know it as one of the finest of all the "pinks." The flowers are large, of perfect shape, and borne on very tall, strong stems. The color is a glorious shade of soft, yet brilliant, light rose. This variety should not be confused with the Iris Marion Cran introduced by Perry in 1919, which is dull Mathew's purple with a light haft, and quite inferior to this later introduction.

$\$ 25.00$ each.

MRS. REUTHE (Ware 1899). S. white, softly veined and shaded pale lilac; F. white, frilled pale blue. 30 inches.

25 cts. each; 65 cts. for $3 ; \$ 2.00$ per doz.

MRS. TINLEY (Bliss 1920). An early-flowering variety producing large blooms of an intense self violet-blue, with a conspicuous orange beard. Vigorous in groweh and a free bloomer. 36 inches.

75 cts. each; $\$ 2.00$ for 3.

MRS. WALTER BREWSTER (Vilmorin 1922). A free-blooming variety on low, branched stems, with many flowers open at a time. S. lavender-blue; F. aniline-blue, veined brown at the haft on a white base; beard yellow. A late bloomer that is very attractive. 36 inches.

$\$ 1.00$ each.

MRS. W. E. FRYER (Fryer 1917) 7.1. S. white, shaded lavender; F. purple-crimson, bordered a lighter shade, veined white from center to base; beard orange. 32 inches.

$50 \mathrm{cts}$. each; $\$ 1.25$ for $3 ; \$ 4.00$ per doz.

NAUSHON (Sturtevant 1920) 7.1. Mauve and pansy-violet; very free flowering. 30 inches. $35 \mathrm{cts}$. each; $85 \mathrm{cts}$. for $3 ; \$ 3.00$ per doz.

NAVAJO (Farr 1913). S. light bronzy-yellow, shaded lavender; F. deep maroon, heavily veined white and yellow; stigmas yellow; deep orange beard. 20 inches.

$25 \mathrm{cts}$. each; $60 \mathrm{cts}$. for $3 ; \$ 2.00$ per doz.

NAZARIN (Foster). A beautiful hybrid of Pallida X Iberica parentage. Almost a pure self-color without veinings. S. light purple-violet; F. a shade deeper, with short, orange beard. A flower of unusually pure coloring and charming style. 24 inches.

$\$ 2.00$ each. 
NEPTUNE (Yeld 1917) 8.1. A fine, tall Iris similar in style and coloring to Halo and Lord of June. S. bright, pale blue; F. rich, dark purple-blue. Large flowers on strong, branched stems. 42 inches. A strong grower, free flowering, and reliable. $50 \mathrm{cts}$. each; $\$ 1.25$ for $3 ; \$ 4.00$ per doz.

NIBELUNGEN (Goos \& Koenemann 1910) 7.3. S. fawn on firse opening, changing to golden-buff; F. red-purple on bronze. Free flowering on stems 30 inches high.

$25 \mathrm{cts}$. each; $60 \mathrm{cts}$. for $3 ; \$ 2.00$ per doz.

NIMBUS (Shull 1924). A tall-growing variety with flowers of largest size. S. light lobelia-violet, with a darker thread edge; F. Cotingapurple. A flower of great distinction that makes a splendid, if somewhat somber, mass in the garden. 44 inches. $\$ 5.00$ each.

NINE WELLS (Foster 1909) 8.0. S. light violet; F. deep purple, with white ground at haft. Large flowers borne on very tall, stout stems. Late flowering. 48 inches. 35 cts. each; 85 cts. for $3 ; \$ 3.00$ per doz.

NUEE D'ORAGE (Verdier 1905) 7.6. S. pale purple-drab to deep, dull lavender; F. Bradley's violet, reticulated maroon on a white ground at the - haft. The large flowers are attractive in their color blending, but lack the substance found in some of the newer Irises. Stalks well and widely branched. 36 inches. $\quad 35 \mathrm{cts}$. each; $85 \mathrm{cts}$. for $3 ; \$ 3.00$ per doz.

OCHRACEA (Denis 1919) 7.9. This striking flower is handicapped by a superfluity of names. It received an Award of Merit from the Royal Horticultural Society, when shown in 1922, under the name Ochracea Caerulea. Later it was cataloged under the name Sunset, and now it is recognized by the American Iris Society as Ochracea. Withall, it is a flower of wonderful coloring. S. yellowish-buff, or real old-gold, finely arched and of great substance; F. coppery-yellow, heavily suffused blue-violet in the center of the segments and prettily reticulated and dotted brown at the haft, with a prominent, deep yellow beard. A fascinating mixture of real pastel shades, yet so bright as to fairly glow in the sunlight. Fine strong grower, exceedingly free flowering, sweetly scented and very late. 30 inches.

$\$ 2.00$ each.

OLIVER PERTHUIS (Millet 1921). A medium-sized flower on the order of Mme. Gaudichau. S. manganese-violet; F. velvety pansy-violet; haft and styles edged amber. A plant of vigorous growth with stems strong and well branched, free flowering.

$\$ 1.50$ each.

OPERA (Vilmorin 1916) 8.7. A very striking Iris of medium size, with flowers of magnificent color. S. bright, rich pansy-violet, shading to brownish-violet at the base; F. a rich, velvety violet-purple. 30 inches.

50 cts. each; $\$ 1.25$ for $3 ; \$ 4.00$ per doz.

ORIFLAMME (Vilmorin 1904) 7.8. One of the largest of the older Irises, on the order of Amas. The large, broad standards are dark lavender, and the long, drooping falls are hortense-violet, shading to white at the haft. A beautiful flower but lacking in substance in comparison with the newer introductions. 30 inches.

50 cts. each; $\$ 1.25$ for $3 ; \$ 4.00$ per doz.

PALLIDIN (Bliss 1921). A large-flowered bicolor on the order of Oriflamme but of better substance. S. clear violet-blue; F. deep, rich violet-purple. Vigorous in growth with branching stalks. 30 inches.

$\$ 2.00$ each.

PARC DE NEUILLY (Verdier 1910) 8.1. A large, late-flowering self of rich coloring that is particularly effective in mass planting. Uniform deep violet-blue, with a yellow beard. Vigorous growth, with strong stems. 30 inches.

$35 \mathrm{cts}$. each; $85 \mathrm{cts}$. for $3 ; \$ 3.00$ per doz. 
PARISIANA (Vilmorin 1911) 7.9. A large flower of good and unusual coloring. S. white ground, dotted and shaded lilac-purple; F. white, frilled at the edge with lilac. 36 inches.

35 cts. each; 85 cts. for $3 ; \$ 3.00$ per doz.

PAULINE (Farr 1913) 7.5. A fine, large flower of pansy-violet on 36-inch stems; prominent, orange beard. A very good red-purple variety; vigorous and free flowering. $35 \mathrm{cts}$. each; $85 \mathrm{cts}$. for $3 ; \$ 3.00$ per doz.

PEAU ROUGE (Cayeux 1923). A brilliant novelty of outstanding coloring. S. coppery-red; F. bronzy blood-red; beard brownish-yellow. In form of flower, it is similar to Ambigu but more brilliant. The stems are 24 inches high and do not branch. Probably the reddest toned Iris yet produced.

$\$ 4.00$ each.

PEERLESS (Dykes 1924). A magnificent flower of enormous size and brilliant coloring, giving the effect of rich, glowing mahogany-red. S. broad and erect, light reddish-violet; F. straight hanging, deep red-purple, with bronze reticulations at the haft; beard rich gold, so brilliant that it lights up the whole flower. Strong in growth and free flowering on well-branched stems. 36 inches.

$\$ 35.00$ each.

PERFECTION (Barr) 7.8. An old Iris that still stands as one of the best of its class. S. light blue-lavender, usually irregularly flaked with deeper blue; F. brilliant, deep violet-purple, with an orange-yellow beard. 30 inches.

25 cts. each; 60 cts. for $3 ; \$ 2.00$ per doz.

PERLADONNA (Perry 1923). A fine, blue self with medium-sized flowers of clear coloring and great texture. S. and F. Dauphin's violet, a shade deeper than Dalmatica, with maroon reticulations at the haft. Stout, branching stems growing full 42 inches high. Introduced by Perry under the name Belladonna.

$\$ 2.50$ each.

PHYLLIS BLISS (Bliss 1919) 8.9. A light rosy-lavender self of medium size. Very delicate and pleasing coloring.

$\$ 1.00$ each.

PIONEER (Bliss 1924). A magnificent new Iris and one of the best redpurples in cultivation. S. large and incurved, colored bright Amparopurple; F. very broad and strong, deep glowing pansy-purple, set off by a bright orange beard. Vigorous and strong in growth, with stems of branching habit. A rich and royal flower of distinctive qualities that assure it a permanent place among the best.

$\$ 10.00$ each.

POCAHONTAS (Farr 1915) 7.7. Very large, orchid-type flower, with elegantly frilled petals. S. white, faintly bordered pale blue; F. pure white. 30 inches. $35 \mathrm{cts}$. each; $85 \mathrm{cts}$. for $3 ; \$ 3.00$ per doz.

PRIMAVERA (Mohr 1926). A new Iris, resulting from a cross between the species Mesopotamica and a little Pumila, blooming with the Intermediates. The very large, shapely flower is pale yellow, deepening toward the center. Vigorous and floriferous.

$\$ 2.00$ each.

PRIMROSE (Sturtevant 1923). A beautiful self yellow of clearer, purer tone than Shekinah. The standards are amber-yellow and the falls a lighter barium-yellow, with haft and styles clear lemon-yellow. A very refined and finished flower, a shade lighter than Gold Imperial. 30 inches.

$\$ 6.00$ each.

PRINCE LOHENGRIN (Mohr 1923). This new Seedling, a cross between Juniata and Lohengrin, is introduced as an improved Lohengrin. It grows nearly a foot caller, has better placed flowers, and is slightly pinker in color. Perfectly hardy everywhere. 
PRINCESS BEATRICE (Barr) 9.5. This true variecy is one of the finest of all the Irises. Unfortunately there is much confusion among the Pallida-cype flowers and various inferior sorts have been sold as Princess Beatrice. S. and F. clear lavender-blue, shading to pale silvery-blue at the base of the petals, and ligheed by a clear orange beard. The falls are well rounded and flaring. Tall and vigorous in growth with broad, lighe green foliage and strong stems. Racher slow in becoming escablished and a shy bloomer the first year. $75 \mathrm{cts}$. each; $\$ 2.00$ for $3 ; \$ 7.00$ per doz.

PRINCESS OSRA (Bliss 1922). A very large, clear Plicaca, with tall stems. Clear white, the S. broadly and the F. more narrowly margined with spots and veinings of soft wisteria-violet and bluish-lavender. The prectiest of the new Plicacas.

$\$ 3.00$ each.

PRINCESS VICTORIA LOUISE (Goos \& Koenemann 1910) 7.2. An early, free-flowering variecy of strong, vigorous growth. S. clear pinard-yellow; F. Rood's violer, bordered sulphur-yellow and shaded to yellow at the haft; beard orange. 30 inches.

$25 \mathrm{cts}$. each; $60 \mathrm{cts}$. for $3 ; \$ 2.00$ per doz.

PROSPER LAUGIER (Verdier 1914) 8.3. An old and well-known "brown" Iris that is very handsome. S. snuff-brown, slightly suffused heliotrope; F. deep plum-violer, veined deeper, heavily reticulated at the base, and wich prominent yellow beard. Growth strong and vigorous. 36 inches.

$35 \mathrm{cts}$. each; $85 \mathrm{cts}$. for $3 ; \$ 3.00$ per doz.

PROSPERO (Yeld 1920). A vigorous, tall-growing variety, bearing enormous flowers of fine shape. S. pale lavender, flushed yellow at the base; F. deep red-purple, with lighter shadings at the margin, heavily marked with brown at the haft. 48 inches. Rated as one of the outstanding foreign introductions and one of the very finest varieties.

$\$ 1.00$ each; $\$ 2.50$ for 3 .

PURPLE KING. A large-flowered red-purple Iris of fine color that blooms with the Intermediates. 36 inches.

$25 \mathrm{cts}$. each; $60 \mathrm{cts}$. for $3 ; \$ 2.00$ per doz.

QUAKER LADY (Farr 1909) 8.4. S. smoky lavender, wich yellow shadings; F. argeratum-blue and old-gold; stigmas and beard yellow. A very atrractive and finished flower of medium size that blooms freely. 36 inches.

35 cts. each; 85 cts. for $3 ; \$ 3.00$ per doz.

QUEEN ALEXANDRA (Barr) 7.5. S. purplish-lilac; F. lilac, reticulated bronze at the base. An old variecy that is much admired.

$25 \mathrm{cts}$. each; $60 \mathrm{cts}$. for $3 ; \$ 2.00$ per doz.

QUEEN CATERINA (Sturcevant 1918) 9.0. A large, iridescent, pale lavender-violet self, white at the haft, with bronzed reciculations and yellow beard. A flower of good form and a coloring that is much admired. One of the finest American introductions. $\$ 1.00$ each; $\$ 2.50$ for 3 .

QUEEN MARY. See Whice Queen.

QUEEN OF MAY (Salter 1859) 7.4. An old standard that is scill one of the most charming "pinks" for mass plantings. S. and F. rose to lizeranpurple; white at the haft, reticulated purple. Vigorous growth with short and high branched scalks. 30 inches.

25 cts. each; 60 cts. for $3 ; \$ 2.00$ per doz.

RAFFET (Vilmorin 1920) 8.1. A very late-flowering variety, larger bur otherwise similar to Áclas. S. Bradley's violet; F. darker, with rich, velvery veinings. Stalks low and well branched. 36 inches.

75 cts. each; $\$ 2.00$ for 3 . 
RAJPUT (Sturtevant 1922). A large, bright violet self of fine form and good substance, exceptional in vigor and growth. 40 inches. $\$ 4.00$ each.

RAMELDO (Mohr 1925). As the name indicates, this is a cross of Ramona and Eldorado. It is an attractive blend of the same type, but taller and darker than either and quite unlike any other we have seen. Perfectly hardy.

$\$ 2.00$ each.

RAMONA (Mohr 1924). A new blend of colors-petunia-violet, flushed cinnamon-brown, lightened up by an orange beard. Fine form and substance and vigorous in growth.

$\$ 2.00$ each.

RED GLORY (Fryer 1920). S. bronze-yellow; F. velvety maroon-red, orange beard. Fragrant. 30 inches.

50 cts. each; $\$ 1.25$ for $3 ; \$ 4.00$ per doz.

REGAN (Hort 1920). A very fine and distinct, rich violet-blue, earlyflowering bicolor, with exceptionally long falls, heavily reticulated brown on a white ground, and canary-yellow beard. The flowers are remarkable for their splendid poise and good shape, and have an unusual satiny sheen that is very pleasing. 42 inches.

$\$ 1.00$ each.

RENE CAYEUX (Cayeux 1924). A glorious and distinct plant of unusual coloring. Very large, shapely flowers. S. white, shaded lilac; F. reddish crimson-violet, reticulated white at the throat. 42 inches. $\$ 12.00$ each.

RENE DENIS (Denis). Large flowers of beautiful and interesting coloring. S. yellow, shading off to a golden yellowish-brown and paling to soft mauve at the apex; F. coppery-rose, shading to gray at the margins, striated with thin maroon lines.

$\$ 3.50$ each.

RHEINGAUPERLE (Goos \& Koenemann 1915). A beautiful, soft rosepink flower on the order of Wild Rose. The falls are broad and brighter in color, in contrast to the high, dome-like form of the standards. A fine variety.

$\$ 2.00$ each.

RHEIN NIXE (Goos \& Koenemann) 8.4. S. white; F, violet-blue, with a white margin. A free-flowering Amoena on nicely-branched stems over 36 inches high. This old variety is hardly surpassed by any of the newer introductions. $\quad 35 \mathrm{cts}$. each; $85 \mathrm{cts}$. for $3 ; \$ 3.00$ per doz.

RICHARD II (Dykes 1914) 7.4. A distinct, clear bicolor that is fine as an individual flower but not very vigorous in growth. S. white; F. velvety prune-purple. 20 inches. A Seedling of Black Prince. $\$ 2.00$ each.

RING DOVE (Foster 1913). S. pale lavender-violet; F. a shade darker, with a band of dark lavender at the throat. Tall, thrifty grower.

50 cts. each; $\$ 1.25$ for $3 ; \$ 4.00$ per doz.

RITA (Mohr 1924). A Trojana X Caterina cross, resulting in a bluepurple self, of the same shade as Mandraliscae and Miranda, but far surpassing these in size. Wonderful stems, branching almost from the ground.

$\$ 1.00$ each.

ROBERT W. WALLACE (Perry 1923). A magnificent, dark Iris of Imperator type, almost the same rich coloring as Archeveque, but a decided improvement. S. arched and nicely frilled, velvety hyacinth-violet; F. very deep, rich purple-black; beard conspicuous orange tipped. Strong and vigorous in growth with low and well-branched stems. 36 inches.

$\$ 5.00$ each.

RODNEY (Bliss 1919) 8.3. A free-flowering Pallida of uniform Dauphin's violet, smooth texture and fine shape. A vigorous grower. 40 inches. 50 cts. each; $\$ 1.25$ for $3 ; \$ 4.00$ per doz. 
ROMANY (Bliss 1919) 8.6. An early and free-flowering variety. S. pale dusky yellow; F. bright, reddish-brown, well reticulated and of good shape.

75 cts. each; $\$ 2.00$ for 3 .

ROMOLA (Bliss 1924). One of the most attractive of the Dominion Seedlings yet introduced, inasmuch as it is the lightest in colorings. The blooms are very large, gracefully formed and delicately toned. S. pale lilac, tinged pale ivory-yellow at the base; F. flat hanging, velvety redviolet, with close, light brown reticulations at the haft. A strong flower with branching stems. 42 inches.

$\$ 25.00$ each.

ROSADO (Mohr 1925). This beautiful, clear, soft pink, tall, stronggrowing Iris of unusual size is literally in a class by itself as the first of its color of Mesopotamica parentage. It has proved hardy and vigorous in the East.

$\$ 7.50$ each.

ROSALBA (Bliss 1919). A richly colored flower of medium size that produces a wonderful mahogany-red effect in mass. A taller and redder Seminole. Very free flowering on well-branched stems. 36 inches.

$\$ 1.00$ each.

ROSE MADDER (Sturtevant 1920). A very lovely and unusual flower of true rose-madder tones. S. light, F. dark and velvety. Tall, and strong in growth. 40 inches.

$\$ 4.00$ each.

ROSEWAY (Bliss 1919) 8.2. S. phlox-purple; F. of a duller shade; orange beard. One of the brightest of the so-called red Pallidas yet grown. Good for landscape plantings. 36 inches.

50 cts. each; $\$ 1.25$ for $3 ; \$ 4.00$ per doz.

ROTA (Goos \& Koenemann). S. bright, silky carmine-pink; F. darker tone, with distinguishable veinings but no border - a brilliant, luminous mass effect in bright sunlight. It is medium, tall and very free-flowering.

$\$ 2.00$ each.

RUBYD (Dykes 1922). A rich, deep, reddish violet-purple, with F. slightly deeper in tone than the S.; beard brilliant aniline-blue, tipped ochreyellow. Vigorous and free flowering. 30 inches.

$\$ 1.50$ each.

RUBY QUEEN (Weed 1923). S. light Mathew's purple; F. Rood's violet, lighter at the edge. A distinct ruby-toned Iris over 36 inches tall.

75 cts. each; $\$ 2.00$ for 3 .

SAN GABRIEL (Dean 1921). An early-flowering Iris of large size on the style of Lady Foster. S. light lavender-violet, arched; F. widely flaring slightly darker in color, finely reticulated dark brown at the haft. Stems tall and well branched. 48 inches.

$\$ 3.00$ each.

SANTA BARBARA (Mohr 1925). A very large and finely formed lavenderblue flower that grows most imposingly on very tall, finely branched stems. 48 inches.

$\$ 7.50$ each.

SAPPHID (Dykes 1922). A beautiful, blue Iris that may best be described as an early-flowering Goldcrest, since it comes in flower about ten days earlier than that variety. The flowers are pure Dauphin's blue, with a conspicuous, brilliant cadmium-yellow beard. Very free-flowering and grows 24 to 30 inches high.

$\$ 2.00$ each.

SARABANDE (Sturtevant 1918) 7.6. This tall-growing Iris has a delightful combination of colors. S. biscuit-colored, with a flush of peach-pink; F. purple, with a wide margin of pink. 42 inches. Vigorous and free flowering.

50 cts. each; $\$ 1.25$ for $3 ; \$ 4.00$ per doz. 
SARPEDON (Yeld 1914) 8.0. S. soft, bluish-violet; F. hyacinth-violet. Large flowers on tall, slender stems. 36 inches.

50 cts. each; $\$ 1.25$ for 3.

SAVIGNIAN (Millet). A Squalens variety of an attractive blend of violet, dahlia-purple, and yellow.

50 cts. each; $\$ 1.25$ for 3 .

SEAGULL (Farr 1923). S. white, dome-shaped; F. white, faintly shaded blue, with a network of narrow blue lines or veins. A distinct, clean color effect. 24 inches.

50 cts. each; $\$ 1.25$ for 3.

SEMINOLE (Farr 1920) 8.3. S. dark violet-rose; F. rich, velvety crimson; brilliant orange beard. A richly-colored and free-flowering variety that is beautiful either as an isolated plant or in mass effect. One of the outstanding varieties from the Farr collection. 24 inches.

$60 \mathrm{cts}$. each; $\$ 1.50$ for $3 ; \$ 5.00$ per doz.

SHEKINAH (Sturtevant 1918) 8.7. S. and F. a pale lemon-yellow, deepening through the center. The first clear yellow of good size and height. A strong grower, nearly 36 inches tall.

$\$ 1.00$ each; $\$ 2.50$ for 3 .

SHERBERT (Sturtevant 1918) 8.1. S. ecru-drab, deepening through cinnamon to purplish-red; F. dahlia-purple, shading lighter at the edges. Tall, well-branched stalks of 48 inches height. $75 \mathrm{cts}$. each; $\$ 2.00$ for 3 .

SHERWIN WRIGHT (Kohankie 1915) 7.6. A vigorous and free-flowering, bright golden-yellow. The color is more dense and brighter than most of the newer and supposedly improved varieties.

35 cts. each; 85 cts. for $3 ; \$ 3.00$ per doz.

SHREWSBURY (Farr 1916). S. rosy-bronze; F. violet-purple, with lighter shadings. The conspicuous, heavy, orange beard stands out in brilliant contrast to the other coloring.

50 cts. each; $\$ 1.25$ for $3 ; \$ 4.00$ per doz.

SILVERADO (Mohr 1924). A sister Seedling of Ramona with quite different but equally distinctive coloring. S. silvered-lavender; F. plumbago-blue, with bright orange beard. Vigorous in growth and perfectly hardy in the East.

$\$ 1.00$ each.

SILVER RIBBON (Williamson 1926). A self-colored flower of heavy texture, deep pink, with a distinct pale band down the center of each fall, prominent, yellow beard. A strong, vigorous grower with stout stems. The large blooms have unusual carrying quality for a pink Iris and make a beautiful showing even at a great distance. 30 inches. $\$ 2.00$ each.

SIMMONE WAISSIERE (Millet 1921). A large bicolor of unusually clear coloring and distinct form, having the falls spread almost horizontal. $S$. light chicory-blue; F. hortense-violet, heavily veined gold and maroon at the haft on a white base; beard conspicuous orange tipped. Similar coloring to Oriflamme but larger and with stiffly flaring falls. A very beautiful variety. 30 inches.

$\$ 3.00$ each.

SIND JKHAT (Sturtevant 1918) 8.4. S. deep lavender, shaded to dark olive at the base; F. lavender-purple-an interesting color blend on the order of Asia. Tall and strong. Late. 48 inches.

$75 \mathrm{cts}$. each.

SIR GALAHAD (Shull 1924). A tall, strong-growing Iris with very large flowers of Magnifica type, but with much better habits and greatly improved substance. The foliage is broad and vigorous and the whole effect is massive. S. mauve; F. pansy-violet. Fragrant. 42 inches.

$\$ 5.00$ each. 
SOLEDAD (Mohr 1924). A cross of Trojana and a yellow Pumila that blooms with the Intermediates. It is a pale yellow self, darker toward the center, that surpasses all the other varieties of its season in clear coloring and pleasing growth.

75 cts. each.

SOLFERINO (Cayeux 1925). A new introduction that gives promise of proving of much merit. A self color of most beautiful, bright lilac-red. Tall, and vigorous growch. 52 inches.

$\$ 20.00$ each.

SOUVENIR DE LOETITIA MICHAUD (Millet 1923). A magnificent Ricardi hybrid with large and beautifully formed self-colored flowers of a delightful shade of lobelia-blue, shading paler blue toward the edges, veined yellow on a white ground at the haft. Tall and free-flowering on well-branched stalks. Over 48 inches. Requires a protected location with perfect drainage.

$\$ 8.00$ each.

SOUVENIR DE MME. GAUDICHAU (Millet 1914) 9.3. One of the most striking and remarkable of all the Irises. A tall, early, deep purple bicolor of an unusual velvety appearance. The fine shape and finish of the flower give great distinction to the plant. 42 inches. $\$ 1.00$ each.

STAMBOUL (Foster 1916). A handsome and fragrant flower of large size of Caterina type. S. light wisteria-violet; F. reflexed, rich violet-blue. 36 inches.

50 cts. each; $\$ 1.25$ for $3 ; \$ 4.00$ per doz.

SUNSET. See Ochracea.

SUSAN BLISS (Bliss 1922). A Seedling of Phyllis Bliss. In color, it is a graduation of tone between Liseran-purple and rose-purple, with a light orange beard. In garden effect, it is a uniform shade of deep rose-pink. One of the best "pink" varieties. 42 inches.

$\$ 3.00$ each.

SWATARA (Farr 1918) 7.9. S. lobelia-blue, suffused bronze-yellow at the base; F. bright violet, with faint olive reticulations at the haft, and brightened by a long beard of intense orange. A medium-sized flower of bright effect: 30 inches. 35 cts. each; 85 cts. for $3 ; \$ 3.00$ per doz.

SWAZI (Bliss 1922). S. bluish-violet; F. velvety, blackish-violet. Magnificent flowers on a vigorous plant with 36 -inch stems. The coloring is nearly the same as the Dominion parent, but the habits and carriage of the plant are far better. The available stocks of this fine Iris have never equalled the demand for it even at the high price.

$\$ 20.00$ each.

SWEET LAVENDER (Bliss 1919) 8.5. S. pale lavender; F. horizontal, very broad and widely expanded, deep rose-lavender, the general effect being a lovely shade of rosy mauve. One of the finest and most distinct Irises. 36 inches.

$\$ 1.50$ each.

SYPHAX (Bliss 1917). S. pale violet; F. deep crimson-purple, boldly reticulated at the haft. A free-flowering variety of which the falls hang almost vertical, giving the flower $a$ unique shape. 30 inches.

50 cts. each; $\$ 1.25$ for 3.

TAFFETA (Cleveland 1920) 6.0. S. lighe heliotrope-gray, flushed deep olive-buff; F. dull lavender. This Iris, probably rated low on account of its size, has a profusion of blooms of an attractive smoky tone that is appealing to many. Growth vigorous. 36 inches.

$75 \mathrm{cts}$. each; $\$ 2.00$ for 3.

TAJ MAHAL (Sturtevant 1921). Well-shaped flowers of large size and good substance on good tall stems. One of the most satisfactory of the new white varieties. 36 inches.

$\$ 4.00$ each. 
TAMAR (Bliss 1920). A lavender-violet self with falls slightly darker than the standards. Vigorous and free-flowering. $75 \mathrm{cts}$. each; $\$ 2.00$ for 3.

TAMERLAN (Vilmorin 1904) 7.4. F. deep purple-violet; S. a little lighter. A tall, large, free-flowering Iris similar to Trojana but earlier. 30 inches.

$35 \mathrm{cts}$. each; $85 \mathrm{cts}$. for $3 ; \$ 3.00$ per doz.

TARTARIN (Bliss 1919) 8.5. An extraordinary variety, producing very large flowers of two distinct shades of pale lilac-lavender-blue. The falls are reticulated bronze at the haft and carry a bright orange beard. 36 inches.

$\$ 1.00$ each.

TENEBRAE (Bliss 1922). A Dominion Seedling of rich, dark coloring that is free flowering and dependable. S. rich violet-purple, tinged dark maroon-purple at the center; F. rich, velvety blackish-purple, reticulated brown at the haft. The flowers are large and finely formed, borne on strong stems 36 inches high.

$\$ 7.00$ each.

TERIAS (Williamson 1925). This flower is best described as a pink Quaker Lady. It is of medium size, a peculiar coppery-pink, distinct and beautiful. A free bloomer. 36 inches.

$\$ 1.00$ each.

THECLA (Williamson 1925). A healthy, vigorous Iris, bearing its beautiful flowers in greatest profusion. $S$. bright, clear mauve; F. spreading, purple. Medium-sized blooms on 30-inch stems. $50 \mathrm{cts}$. each.

THESEUS (Newlands 1923). A beautiful, white flower of medium to large size, remarkable for the deep golden reticulations on the falls. One of the most distinct white varieties, tall and vigorous in growth, and more reliable than some of the other Irises of the class. 36 inches.

$\$ 10.00$ each.

THORBECKE (Before 1897) 6.8. One of the older Irises, bearing flowers of medium size, and one of the most attractive varieties of our entire list. S. clear white that never come blotched from the color of the falls; F. deep, rich, velvety purple. Free flowering and reliable. 30 inches.

$35 \mathrm{cts}$. each; $85 \mathrm{cts}$. for $3 ; \$ 3.00$ per doz.

TITAN (Bliss 1919). The largest flower of the Dominion race. Enormous blooms with spreading falls of such great substance that the flowers, in spite of their size, stand stiff and erect to the last. S. arching, three inches broad, of light violet-blue; F. broad and smooth, violet-purple, deeper in the center of the blade and with conspicuous reticulations of white on the haft. Very strong plant with broad, thick leaves and massive stems; stiff and wide-branching spikes; very free flowering. 36 inches.

$\$ 6.00$ each.

TOM TIT (Bliss 1919) 8.0. A unique plant that is greatly admired when seen in bloom. Flowers of a deep self violet-blue come three or four on a stem. The falls stand almost hotizontal. A very.decorative little plant for border use: 18 inches. 50 cts. each; $\$ 1.25$ for 3.

TRIANON (Vilmorin 1921). A pleasing tan blend that is late flowering and very distinct. S. pale buff with just a suspicion of rose; F. of similar color, deepening to lavender. 30 -inches. $50 \mathrm{cts}$. each; $\$ 1.25$ for 3.

TRISTRAM (Bliss 1919) 8.2. S. white, tinted lavender; F. velvety, blackish-purple, heavily veined white at the base. A distinct flower of black-and-whice effect. 27 inches. $50 \mathrm{cts}$. each; $\$ 1.25$ for 3 .

TROJANA (Species) 8.1. S. light lavender-violet; F. amethyst-violet, veined darker. Growth moderate, over 36 inches.

$35 \mathrm{cts}$. each; $85 \mathrm{cts}$. for $3 ; \$ 3.00$ per doz. 
TROOST (Denis 1908) 8.4. Large flowers of very brilliant coloring and good form. S. deep, rosy-pink; F. paler, heavily veined violet, which changes to brown at the haft. The general mass effect is a ravishing bright pink flower. 24 inches.

60 cts. each; $\$ 1.50$ for $3 ; \$ 5.00$ per doz.

TROPIC SEAS (Shull 1924). A sister plant to Morning Splendor and Julia Marlowe, representing the blue extreme, as Morning Splendor represents the red extreme, of this family. S. Dauphin's violet; F. velvety mulberry-purple to haematoxylin-violet, giving a very deep bluepurple general effect, and conspicuously lit up by a rich golden beard. Large flowers, splendid growth, fragrant. 50 inches. \$5.00 each.

TRUE CHARM (Sturtevant 1920). A delightful as well as an individual form of flower and style of growth. Blooms white, with margins delicately etched with blue-lavender. 40 inches. $\$ 1.50$ each.

TURCO (Vilmorin 1921). S. purplish-lilac; F. lobelia-violet, both S. and F. marked with bronze at the haft; orange beard-an unusual color effect.

50 cts. each; $\$ 1.25$ for $3 ; \$ 4.00$ per doz.

VALENCIA (Mohr 1926). An orange-buff self, selected for its bright and unusual coloring. Flowers of medium size on 24-inch stems.

$\$ 4.00$ each.

VINCENTIO (Hort 1921). A bold purple bicolor with large, spreading, rich red-purple falls. A good companion plant to Hermione, which it resembles, though somewhat redder in color tone. The foliage of these two varieties is quite distinct and unlike any other variety. 36 inches.

$\$ 3.00$ each.

VINGOLF (Goos \& Koenemann). S. near cream-color; F. deep, rich, velvety violet-blue, with light, clear-cut margins-a new and fascinating color combination.

$\$ 2.00$ each.

VIOLACEA GRANDIFLORA (1860). A good, clear violet-blue Pallida, similar in color and form to Mandraliscae.

25 cts. each; 60 cts. for $3 ; \$ 2.00$ per doz.

VIRGINIA MOORE (Shull 1921) 8.1. At the time of its introduction this was the largest and finest yellow Iris. A tall self of the bright chromeyellow of the Lemon Lily, Hemerocallis flava, slightly veined on the falls. Strong and vigorous in growth. 30 inches: $75 \mathrm{cts}$. each; $\$ 2.00$ for 3.

WALHALLA (Goos \& Koenemann 1908). An Intermediate. S. pale lavender-blue; F. velvety violet-purple. Very large flowers on 30-inch stems. $35 \mathrm{cts}$. each; $85 \mathrm{cts}$. for $3 ; \$ 3.00$ per doz.

WEDGEWOOD (Dykes 1923). A gloriously rich, true blue self. Both S. and F: are a uniform color of "Wedgewood" blue, shaded to white at the base of the segments with a white- beard. The large; prominent flowers are freely produced on welt-branched stems 42 inches high. A flower of the same finished effect as Aphrodite among the pinks.

$\$ 7.50$ each.

W.: F. CHRISTMAN :(Fryer 1917): S. white, tinged violet, some flaked and reticulated with violet on the inner side; $F$. purple, reticulated white, with a light border; beard yellow; fragrant. 22 inches.

$25 \mathrm{cts}$. each; $60 \mathrm{cts}$. for $3 ; \$ 2.00$ per doz.

WHITE KNIGHT (Saunders 1916) 8.3. A pure white flower, with only very light reticulations at the haft. Medium size, fine form, and good substance. 24 inches: A better grower than La Neige.

$50 \mathrm{cts}$. each; $\$ 1.25$ for 3. 
WHITE QUEEN (Geylenkek). Syn. Queen Mary. A snow white flower with throat and beard greenish-white. A prolific bloomer several days earlier than White Knight. 30 inches. $\$ 1.00$ each; $\$ 2.50$ for 3.

WILLIAM MOHR (Mohr 1925). This is probably one of the most remarkable Irises ever raised. It was obtained by the late Wm. Mohr from a cross of the Pogoniris Parisiana with pollen from the rare and beautiful Oncocyclus Gatesii. As Mr. Mohr considered it his finest achievement, it has been named in his memory. The ground color is pale lilac, standards flushed darker, and the whole flower beautifully veined manganese-violet. It is very large with broad, rounded segments of fine form and great substance. Stems strong and rigid. 20 to 24 inches. This interesting variety gives promise of being one of the finest additions to our Iris list. It has all the weird charm of I. Susiana, the Mourning Iris, with sufficient vigor to withstand the cold winters of the North.

$\$ 25.00$ each.

WILD ROSE (Sturtevant 1921). A daintily colored pink flower of unusual charm. In some lights it has the exact shade of the Prairie rose, but with a silvery finish of unusual smoothness and firm texture. 33 inches.

$\$ 3.00$ each.

W. J. FRYER (1917) 8.3. S. bright, glistening yellow, slightly ruffled; F. reddish-purple, with narrow yellow border, white at the haft, beautifully reticulated old-gold. 34 inches.

$\$ 1.00$ each; $\$ 2.50$ for 3.

WYOMISSING (Farr 1909) 7.2. S. creamy-white, suffused delicate soft rose; F. deep rose, shading to flesh at the borders. As an individual flower this Iris lacks character, but in mass plantings it has a delicate opalescent-pink effect not obtainable from any other variety. It flowers early, is vigorous in growth and free blooming. 30 inches.

35 cts. each; 85 cts. for $3 ; \$ 3.00$ per doz.

YOLANDE (Millet 1923). A Seedling of Mme. Gaudichau, of great vigor bearing very large flowers, that are said to be an improvement on that grand Iris. S. and F. are rich, velvety, dark blue-purple. A very choice variety.

$\$ 5.00$ each.

ZOUVE (Vilmorin 1922). A curious Plicata with markings similar to the variety Mary Garden. S. white, suffused with lilac; F. white, heavily dotted and reticulated manganese-violet at the edges; haft and style flushed antimony-yellow. 30 inches. An early-flowering variety that appeals to those who like the odd things.

50 cts. each; $\$ 1.25$ for $3 ; \$ 4.00$ per doz.

ZUA (Crawford 1914) 7.5. An early-flowering, dwarf-growing variety with large blooms of elear white, slightly tinted lilac. S. and F. have a curiously crinkled texture like crepe paper. 12 to 18 inches. The flower is similar in color to Florentina alba but with more crinkled texture and dwarfer habits.

50 cts. each; $\$ 1.25$ for $3 ; \$ 4.00$ per doz.

ZULO (Bliss 1925). A Dominion Seedling and a sister variety to Swazi. It is late flowering, and has all the Dominion features of rich color, heavy texture, and long-lasting quality. S. clear, rich, steely anilineblue; F. fine, dark, rich, velvety-purple. 36 inches. \$15.00 each.

ZWANENBURG (Denis 1909) 8.5. An interesting and curiously colored cross between the dwarf bearded Lutescens Aurea and the Oncocyclus, Susiana, that is vigorous and floriferous, blooming with the Intermediates. S. cream, blotched greenish-buff; F. chamois to olive. 18 inches. 
INDIAN SPRING FARMS, INC.

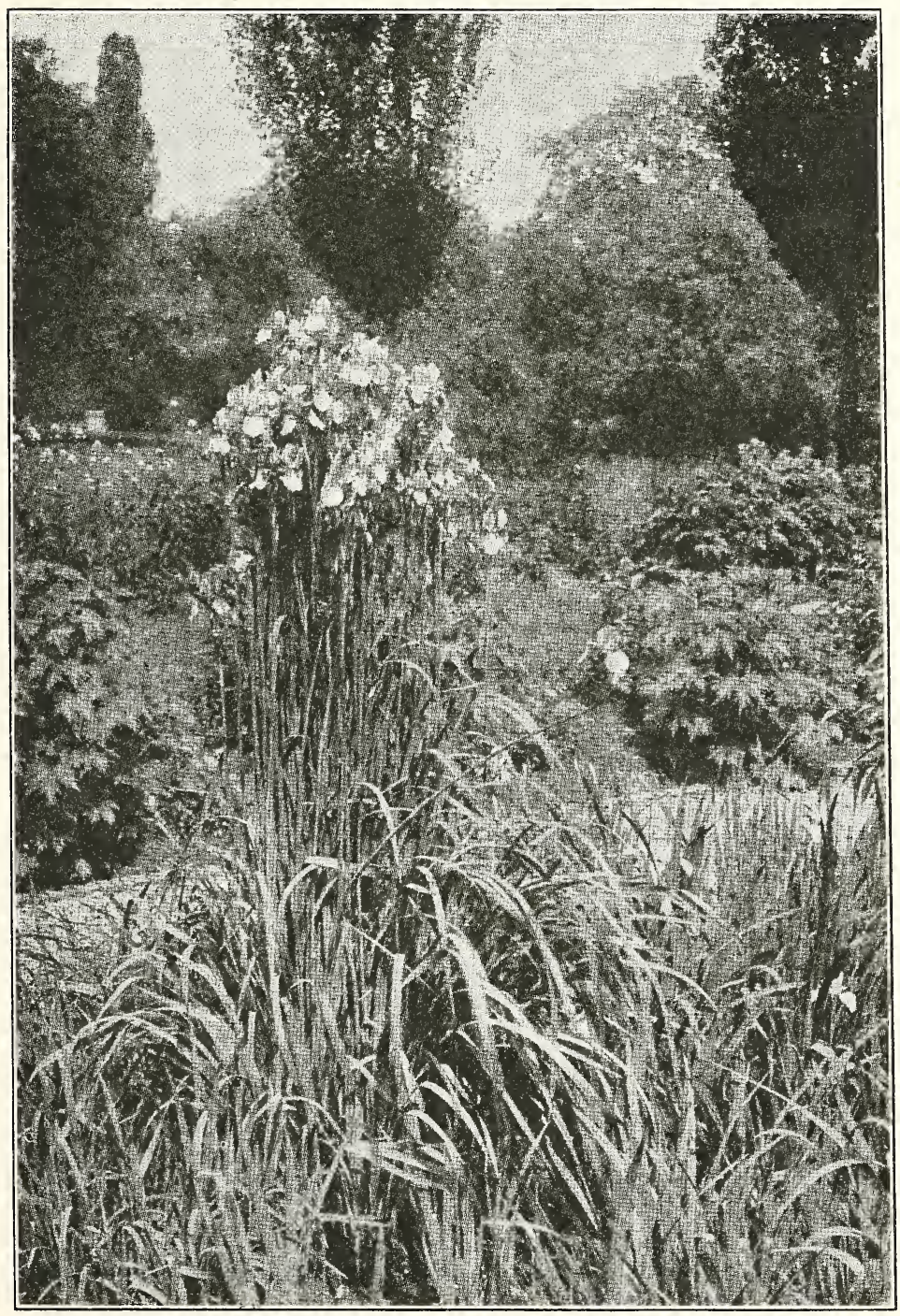

A fine clump showing the habit of the best Siberian Iris 


\section{Beardless Irises}

This group, which includes the various Siberian varieties and the Spurias as well as some of the Species, is one of the most beautiful of all the Iris classes, and is one of the easiest to grow. They do well when planted in the cultivated borders or in any strong, rich soil, and are thoroughly at home in moist places and when massed along the watersides. They are very floriferous, and their grass-like foliage and long stems make them especially desirable for cutting. Beardless Irises should only be moved in early spring or in the fall. See cultural directions, page 5.

DOROTHEA K. WILLIAMSON (Williamson 1918). A hybrid of the beardless species Fulva and Foliosa. Large, velvety flowers of the most vivid purple. Generally considered one of the very finest Beardless Irises. Excellent as a cut-flower. 30 inches. $75 \mathrm{cts}$. each.

ENSATA (Species). A distinct Asiatic species with long, arching, grassy foliage and small, pale gray-blue flowers on long, slender stems.

50 cts. each; 3 for $\$ 1.25$.

PSEUDACORUS (Species). The Common Water Iris. A plant of tall, sturdy growth with sheaves of rich green foliage that are very decorative. The flowers are bright golden-yellow, of medium size. Admirably adapted for damp and boggy locations, but will succeed equally well in ordinary rich garden soil.

35 cts. each.

SIBIRICA (Species). Syn. Siberian Blue. Good blue flowers, somewhat smaller than most of the named hybrids. Desirable for naturalized mass plantings.

25 cts. each; $\$ 1.50$ per doz.; $\$ 8.00$ per 100 .

SIB., BLUE KING (Col. by Barr). S. and F. deep blue. Tall stems with graceful, grassy foliage. One of the best for cutting.

$35 \mathrm{cts}$. each; $85 \mathrm{cts}$. for $3 ; \$ 2.50$ per doz.

SIB., BUTTERFLY (Cleveland 1920). A light blue variety of medium height that blooms in midseason. Back of the falls solid in color.

$\$ 1.00$ each.

SIB., EMPEROR (Named by Wallace). A noble form of Japanese origin. The falls are large and circular, and the whole flower is deep violet-blue. One of the finest of the Sibirica group.

$\$ 1.00$ each; $\$ 2.50$ for 3.

SIB., FLORRIE RIDDLER (Perry before 1920). A tall, dark blue that seems to be better than Perry Blue, especially being larger. Backs of the falls shade lighter at the center. Tall and free flowering. $\$ 1.50$ each.

SIB., PEGGY PERRY (Perry 1912). Dark blue-violet. Back of the falls shading lighter at the center. Medium height, midseason. \$1.00 each.

SIB., PERRY BLUE (Perry 1912). A tall and particularly beautiful variety, universally considered the finest I. Sibirica yet introduced. Large, well-formed flowers on very tall stems. S. sky-blue; F. broad, standing at right angles, "Old China" Blue. 36 inches.

$\$ 1.00$ each; $\$ 2.50$ for 3.

SIB., PIGMY (Perry 1912). A pretty, compact-growing variety with medium-sized flowers of a uniform shade of dark violet. 18 inches.

$50 \mathrm{cts}$. each. 
SIB., RED EMPEROR (Cleveland). S. wine-red, but always with a little blue on the edge; F. one edge blue, other edge wine-red, heavily veined blue all over; haft chocolate-an odd, patchy color design. Large flowers on medium height stems.

$\$ 3.00$ each.

SIB., SANGUINEA. Syn. Orientalis. Very large, rich, deep purple. One of the most beautiful flowers.

50 cts. each.

SIB., SKYLARK. Slightly darker in color than Perry's Blue. Back of the falls lighter toward the center; spathe-valves edged red. 75 cts. each.

SIB., SNOW QUEEN. A lovely form that should be included in every collection. The petals are broad and full, of snowy whiteness, with a rich golden-yellow blotch.

35 cts. each.

SIB., SUNNYBROOK (Cleveland 1920). A dwarf variety that blooms racher low in the foliage. Flowers of a delightful shade of medium blue.

$50 \mathrm{cts}$. each.

SIB., TRUE BLUE (Fryer 1919). One of the best of the blue Sibiricas. The falls are as good or better than Perry's Blue and the standards are a shade darker. The flowers are borne on stiff stems, 30 inches high.

$35 \mathrm{cts}$. each; $85 \mathrm{cts}$. for 3.

SPURIA, MONSPUR (Foster). A fine cross between the species Monnieri $\mathrm{X}$ Spuria. A vigorous plant with bold, sword-like foliage and stout, rigid stems, well furnished with large pale blue flowers. 48 inches. This handsome variety is well adapted for a waterside or damp border.

$\$ 1.00$ each.

SPUR., MRS. A. W. TAIT. A beautiful variery of clear porcelain blue.

50 cts. each.

SPUR., OCHROLEUCA (Species). The Yellowband Iris. A noblegrowing, hardy plant, producing large flowers of ivory whiceness, with orange-yellow at the throat, of stout texture, lasting in beauty for days. 72 inches.

$75 \mathrm{cts}$. each.

SPUR., SHELFORD GIANT (Foster). A cross between Ochroleuca X Aurea, of giant growth, often six feet high. S. creamy-yellow; F. cream, with broad orange blotch. Very vigorous and handsome.

$\$ 3.00$ each.

TECTORUM. A species of the Evansia group-the lovely Roof Iris of China, where it is frequently seen growing on the roofs of the houses. Flat blue-purple flowers, with a conspicuously fringed white crest. The foliage is distinctly broad and arched in growth. 12 inches. $\$ 1.00$ each.

\section{ris \\ Special Collection Offers}

IRIS COLLECTION A. Twenty named varieties of choice Irises, our selection from our catalog list of desirable kinds, to cover the range of colors and season of bloom, values up to $50 \mathrm{cts}$. each. Each variecy separately labeled.

Twenty Named Varieties for $\$ 4.50$.

IRIS COLLECTION B. Your selection of 10 named varieties priced at 50 cts. each or less, all for $\$ 3.75$.

IRIS COLLECTION S. Three distinct Siberian Irises, named varieties that will make a distinct addition to any garden, separacely labeled, for $\$ 1.00$.

Shipment in early spring or fall 
OUR "STANDARD" IRIS COLLECTION. These twelve distinct Irises are worthy of a place in any garden, even in comparison with the newer novelties selling at higher prices. We have selected them as our recommendation for a first planting of the standard varieties to be had at reasonable prices.

Caprice. Reddish-purple

Celeste. Delicate lavender-blue

Fairy. White, bordered blue . . . . . . . . . $\quad .25$

Gertrude. Deep violet-blue . . . . . . . . . . 25

Isoline. Lilac-pink and purplish-rose . . . . . . $\quad .35$

Lohengrin. Violet-mauve . . . . . . . . . . .25

Monsignor. Violet and purple-crimson . . . . . $\quad .25$

Prosper Laugier. Coppery-crimson and maroon . . $\quad .35$

Quaker Lady. Smoky lavender, yellow and blue. . $\quad .35$

Queen of May. Early pink . . . . . . . . . .25

Rhein Nixe. White and violet-blue . . . . . . . 35

Sherwin Wright. Golden yellow . . . . . . . . .35

This "Standard" Collection for $\$ 2.25$

Total $\overline{\$ 3.50}$

THE "POPULAR" COLLECTION. This selection of twelve interesting Irises makes a desirable planting of itself, or makes a balanced addition to our "Standard" collection. Each is a popular variety of distinct character and proven merit.

Alcazar. Grand, violet and purple

$\$ .35$

Caterina. Soft lavender-blue . . . . . . . . $\quad .50$

Cluny. Bluish-violet . . . . . . . . . . . 60

Neptune. Rich blue and purple . . . . . . . . 50

Opera. Richest violet-purple . . . . . . . . . $\quad .50$

Sarabande. Rosy tan and purple . . . . . . . . $\quad .50$

Seminole. Brilliant crimson . . . . . . . . . . .60

Tom Tit. Deep violet-blue. . . . . . . . . . . $\quad .50$

Tristram. White and blackish-purple . . . . . . $\quad .50$

Troost. Deep rosy pink, veined violet . . . . . . $\quad .60$

White Knight. Pure white. . . . . . . . . . . $\quad .50$

Zouave. Cream white, spotted violet . . . . . $\quad .50$

This "Popular" Collection, 12 varieties, for $\$ 5.00$ Total $\overline{\$ 6.15}$

THE "VERY BEST" COLLECTION. Here are sixteen Irises that are the cream of the entire list. Each is a proven variety that has stood the test of time and rates near the top in its color class. Where a few of the true aristocrats are wanted, we recommend this list.

94 Ambassadeur. Reddish-violet and rich purple-maroon $\$ \quad .90$

84 Anna Farr. Clear white, bordered pale blue . . . . 1.00

92 Asia. Blended lavender, yellow and violet-purple . . 3.00

94 Ballerine. Very large, light blue-violet . . . . . . 1.00

85 Dream. Soft, clear pink. . . . . . . . . . . 1.00

90 Lent A. Williamson. Fine, vigorous, violet and purple $\quad .50$

91 Lord of June. Very large, blue and lavender-violet . $\quad 1.00$

85 Medrano. Reddish-copper and dark crimson-purple . 1.00

85 Mme. Chobaut. White, sprinkled yellow and wine red $\quad .60$

Mother of Pearl. Iridescent pale bluish-lavender . . $\quad 1.00$

79 Ochracea. Rich gold, flushed blue . . . . . . . 2.00

95 Princess Beatrice. Silvery lavender-blue . . . . $\quad .75$

Prospero. Lavender, flushed yellow, and reddish-purple $\quad 1.00$

90 Queen Caterina. Iridescent pale lavender-violet . . 1.00

87 Shekinah. Pale yellow, large and fine . . . . . . 1.00

93 Souvenir De Mme. Gaudichau. Rich deep velvety-pur. $\quad 1.00$

This "Very Best" Collection for $\$ 15.00$

Total $\overline{\$ 17.75}$ 


\section{Irises for Mass Plantings}

xis

Irises are widely used for mass plantings in landscape work and for naturalizing along waterways, on sunny slopes and as borders along paths and driveways. For such use they should be planted in quantities to give quick effect and a show of color.

We are able to supply the following comprehensive list of varieties in quantities for large plantings at very reasonable prices. For detailed descriptions see alphabetical list.

\begin{tabular}{|c|c|c|c|c|c|c|c|c|}
\hline & & & & Each & $\begin{array}{l}\text { Lots of } \\
25\end{array}$ & $\begin{array}{c}\text { Lots of } \\
50\end{array}$ & & $\begin{array}{l}\text { ots of } \\
100\end{array}$ \\
\hline A. E. Kunderd & . & • & . & $\$ .35$ & $\$ .20$ & $\$ .18$ & $\$$ & .15 \\
\hline Aixo . . . & . & . . & . & .25 & .15 & .13 & & .10 \\
\hline Albert Victor . & - & . . & . & .35 & .20 & .18 & & .15 \\
\hline Amas . . . & - & . . & . & .35 & .20 & .18 & & .15 \\
\hline Arsace & - & - . & • & .50 & .25 & .23 & & .20 \\
\hline A. W. Blakeley & - & . . & . & .35 & .20 & .18 & & .15 \\
\hline Barrelane & . & . . & - & .50 & .25 & .23 & & .20 \\
\hline Canary Bird & . & . . & . & .25 & .15 & .13 & & .10 \\
\hline Caprice . & . & . . & . & .25 & .15 & .13 & & .10 \\
\hline Celeste. & . & - & . & .25 & .15 & .13 & & .10 \\
\hline Cherubim & . & - & . & .25 & .15 & .13 & & .10 \\
\hline Clarence Wedge & & . . & . & .35 & .20 & .18 & & .15 \\
\hline Dr. Andrist & . & . . & . & .35 & .20 & .18 & & .15 \\
\hline Dr. Mantor & . & . . & . & .35 & .20 & .18 & & .15 \\
\hline Eldorado . & . & - . & - & .35 & .20 & .18 & & .15 \\
\hline Fairy . . & . & . . & . & .25 & .15 & .13 & & .10 \\
\hline Flavescens & - & .. & - & .25 & .15 & .13 & & .10 \\
\hline Florentina alba & . & . . & . & .25 & .15 & .13 & & .10 \\
\hline Gertrude . . & . & . . & - & .25 & .15 & .13 & & .10 \\
\hline Golden Fleece & . & . . & . & .25 & .15 & .13 & & .10 \\
\hline Golden Plume & . & . & . & .25 & .15 & .13 & & .10 \\
\hline G. W. Peake & • & 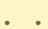 & . & .35 & .20 & .18 & & .15 \\
\hline Ignacite & • & . & . & .25 & .15 & .13 & & .10 \\
\hline Lent A. William & son & n & • & .50 & .30 & & & \\
\hline Lohengrin & . & . & . & .35 & .20 & .18 & & .15 \\
\hline Loreley... & - & 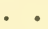 & - & .25 & .15 & .13 & & .10 \\
\hline Mme. Chereau & $\theta^{\circ}$ & - & - & .25 & .15 & .13 & & .10 \\
\hline Mauvine & . & . & . & .35 & .20 & .18 & & .15 \\
\hline M. G. Peters . & . & . & . & .35 & .20 & .18 & & .15 \\
\hline Monsignor. & . & 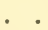 & . & .25 & .15 & .13 & & .10 \\
\hline Mrs. Reuthe. & . & . & - & .25 & .15 & .13 & & .10 \\
\hline Mrs. Sanford . & . & . & . & .35 & .20 & .18 & & .15 \\
\hline Nuee d'Orage. & • & . & . & .35 & .20 & .18 & & .15 \\
\hline Oriflamme & . & • & . & .50 & .25 & .23 & & .20 \\
\hline Parisiana & $\bullet$ & • & . & .35 & .20 & .18 & & .15 \\
\hline Perfection & . & . & . & .25 & .15 & .13 & & .10 \\
\hline Prosper Laugier & & . & . & .35 & .20 & .18 & & .15 \\
\hline Purple King & • & & • & .25 & .15 & .13 & & .10 \\
\hline Queen of May & r. & 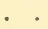 & • & .25 & .15 & .13 & & .10 \\
\hline Stamboul. . & . & 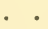 & $\bullet$ & .50 & .25 & .23 & & .20 \\
\hline Tamerlan. & . & . & • & .35 & .20 & .18 & & .13 \\
\hline Walhalla & & . & $\bullet$ & .35 & .20 & .18 & & .15 \\
\hline W. F. Christmar & & . . & 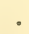 & .25 & .15 & .13 & & .10 \\
\hline Zephyr . . . & . & . . & . & .25 & .15 & .13 & & .10 \\
\hline
\end{tabular}




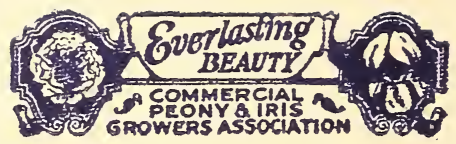

